\section{Tüketicilerin Kombi Tercihlerini Etkileyen Faktörler: Teknoloji Kabul Modeli Çerçevesinde Bir Araştırma}

\author{
Volkan Ozbek $^{\text {a }}$, Izay Tahtaci ${ }^{\mathrm{b}}$
}

Öz: Bu araştırmanın temel amacı, tüketicilerin doğalgaz kombi tercihlerini etkileyen faktörleri Teknoloji Kabul Modeli kapsamında belirlemektir. Araștırma modelinde, teknoloji kabul modeli değişkenlerinin yanı sıra kombi tercihinde etkili olacağı düşünülen algılanan risk ve subjektif norm değişkenleri yer almaktadır. Araştırma amacına ulaşmak için son bir yılda doğalgaz kombi cihazı satın almış tüketiciler arasından yargısal örnekleme yöntemiyle seçilen 267 kişiye çevrimiçi anket uygulanmıştır. Toplanan verilerin analizinde yapısal eşitlik modellemesi kullanılmıştır. Yapılan analizler sonucunda elde edilen bulgular değerlendirildiğinde, algılanan kullanım kolaylığı, algılanan fayda, algılanan risk ve subjektif norm değişkenlerinin tutum üzerinde etkili olduğu sonucuna ulaşılmıştır. Ayrıca, bu araştırma özelinde sınanan, tutum değişkeni ile niyet değişkeni arasındaki ilişkinin pozitif ve istatistiksel olarak anlamlı olduğu gözlenmiştir. Bunun yanı sıra, subjektif norm değişkeni ile algılanan fayda değişkeni arasında beklenen ilişki bu çalışma özelinde doğrulanamamıştır.

\section{Factors Affecting Combi Boiler Preferences of Consumers: A Study in Context of Technology Acceptance Model}

Abstract: The main purpose of this research is to determine the factors affecting the combi boiler preferences of consumers within the scope of the Technology Acceptance Model. In the research model, as well as the Technology Acceptance Model variables, there are perceived risk and subjective norm variables that are thought to be effective in combi boiler preference. In order to achieve the research aim, an online questionnaire was applied to 267 people who purchased natural gas combi boilers in the last year, selected by guided sampling method. Structural equation modeling was used in the analysis of the collected data. When the findings obtained as a result of the analyzes were evaluated, it was concluded that the variables of perceived ease of use, perceived benefit, perceived risk, and subjective norm were effective on attitude. In addition, it was observed that the relationship between the attitude variable and the intention variable, which was tested in this study, was positive and statistically significant. In addition, the expected relationship between the subjective norm variable and the perceived benefit variable could not be confirmed in this study.
Anahtar Sözcükler: Teknoloji Kabul Modeli, Doğalgaz Kombi Cihazı, Algılanan Risk, Subjektif Norm

JEL: M30, M31

$\begin{array}{ll}\text { Geliş } & : 25 \text { Ekim } 2021 \\ \text { Düzeltme } & : 28 \text { Aralık } 2021 \\ \text { Kabul } & : 17 \text { Ocak } 2022 \\ \text { Tür } & : \text { Araştırma }\end{array}$

Keywords: Technology Acceptance Model, Natural Gas Combi Boiler, Perceived Risk, Subjective Norm

JEL: M30, M31
Received : 25 October 2021

Revised : 28 December 2021

Accepted : 17 January 2022

Type : Research

a Assoc. Prof., PhD., Balikesir University, Burhaniye School of Applied Sciences, International Trade Department, Balikesir, Turkiye, vozbek@balikesir.edu.tr (ORCID ID: 0000-0002-2140-2709)

b Balıkesir University, Institute of Social Sciences, International Trade and Marketing Department, Balikesir, Turkiye, tahtacizay@gmail.com (ORCID ID: 0000-0002-5725-8673) 


\section{Giriş}

Türkiye'de iç mekân ısıtmasında doğalgaz kullanılmaya başlanmadan önce, ağırlıklı olarak kömür kullanılmasından dolayı hava kirliliği o kadar yüksek boyutlara ulaşmıştır ki ikame bir ısıtma sistemine ihtiyaç duyulmaya başlanmıştır (Engin, 2010: 235). Bu noktada kullanılmaya başlanan doğalgaz, her geçen sene daha da yaygınlaşmakta ve hava kirliliği gibi çevresel faktörler kullanıma bağlı olarak azalmaktadır. Türkiye, genç nüfusu, kişi başına artan enerji talebi, hızla büyüyen kentleşme ve ekonomik kalkınma ile son yıllarda dünyanın en hızı büyüyen enerji pazarlarından biridir (Erdoğdu, 2010: 211). Ekonomik kalkınma ile birlikte, evlerde de doğalgazlı ısıtma sistemlerinin kullanımının hızlı bir biçimde yaygınlaştığı söylenebilir. Bu gelişmeler neticesinde, ısıtma sektöründe kombi kullanımı oldukça artmıştır (Ertuğrul ve Aytaç, 2012: 82).

Türkiye'de ilk olarak 1988 yılında Bulgaristan sınırından Ankara'ya uzanan bir hat inşa edilmesiyle beraber, Ankara'da doğalgazlı ısıtma sistemlerine geçilmiştir. Daha sonraki yıllarda hat güzergahı üzerindeki diğer dört şehirde (i̇stanbul, Kocaeli, Bursa ve Eskişehir) doğalgazlı ısıtma sistemleri kullanılmaya başlanmıştır (Sarak ve Satman, 2003: 929). 1990'lardan bugüne gelinceye kadar Türkiye'nin birçok yerinde kullanımı yaygınlaşan kombilerin pazar payı da aynı ölçüde artmaktadır. Son iki yıl için yayımlanan kullanım verileri incelendiğinde, 2019 yılında konutlarda doğalgaz kullanımı 14.396,42 milyon sm³ düzeylerindeyken, 2020 yılında bu rakamın 15.613,23 milyon sm ${ }^{3}$ seviyesine ulaştığı gözlenmiştir (Enerji Piyasası Düzenleme Kurumu, 2020).

Yapılan literatür incelemesi çerçevesinde, pazar payı her geçen gün artan iklimlendirme sektörüne ve bu sektörün önemli bir ürünü olan doğalgaz kombi ürünlerine yönelik tüketici davranışlarının yeterli düzeyde araştırılmadığı gözlenmiştir. İklimlendirme sektörünün ürünü olan kombiler pazarlama disiplini bağlamında incelendiğinde; bu ürünlerin beğenmeli mallar kategorisinde yer aldığı ve kolayda mallara göre daha pahalı olup nadiren satın alınan ürünler olduğu söylenebilir. Tüketicilerin, beğenmeli malları satın alma aşamasında, kalite, fiyat ve ürünün uygunluğu gibi konularda özenli bir şekilde karşılaştırma yaptıkları göz önüne alındığında (Murphy ve Enis, 1986); onların doğalgaz kombi cihazını satın alırken spesifik olarak bir ürünü tercih etmelerine sebebiyet veren faktörlerin incelenmesinin önemli olduğu düşünülmüştür. Bu bağlamda yapılan literatür taraması sonucunda tüketicilerin kombi tercihini etkileyen faktörlerin, Teknoloji Kabul Modeli çerçevesinde incelenmesi uygun görülmüştür.

Tüketicilerin bir ürüne yönelik öncelikle, olumlu veya olumsuz bir tutum geliştirdikleri bilinen bir gerçektir. Bu çalışma özelinde tutumu etkileyebileceği düşünülen değişkenler; algılanan risk, algılanan kullanım kolaylığı, algılanan fayda ve subjektif normdur (Shih, 2004; Ha ve Stoel, 2009; Yaghoubi, Motlaq, Moghadam ve Motlaq, 2010; Wu ve Chen, 2014). Doğalgaz kombi cihazına yönelik olumlu tutum geliştiren tüketicilerin, bu cihazı satın almaya yönelik bir niyet oluşturması beklenebilir. Öte yandan, Teknoloji Kabul Modeline ek olarak algılanan risk ve subjektif norm değişkenlerinin çalışma kapsamına dahil edilmiş olmasının nedeni, tüketicilerin doğalgaz kombi cihazı satın alırken risk algısının yüksek olacağı ve onlar için önemli olan kişilerin fikirlerini önemseyerek bir seçim yapacağı düşüncesidir.

Yukarıda ifade edilen araştırma kurgusundan hareketle, öncelikle bir literatür çalışması yapılarak Kuramsal Çerçeve başlıklı ikinci bölümde ilgili alanyazına ilişkin bilgiler sunulmuştur. Ardından üçüncü bölümde araştırmanın hipotezleri ve hipotezlerin gerekçeleri anlatılmıştır. Bir sonraki bölüm olan dördüncü bölümde araştırmanın yöntemi yer almaktadır. Beşinci bölümde araştırma verilerinin analiz edilmesi ile ortaya çıkan bulgulara yer verilmiştir. Altıncı ve son bölümde ise çalışmada elde edilen sonuçlar sunulmuş; ilgili paydaşlara önerilerde bulunularak çalışma tamamlanmıştır.

\section{Kuramsal Çerçeve}

Teknoloji Kabul Modeli (TKM) Fred D. Davis tarafından 1986 yılında geliştirilmiştir. Model ilk olarak bireylerin bilgi teknolojilerini benimseme ve kullanma niyetlerini ölçmek amacıyla ortaya çıkmıştır. Zamanla yapılan birçok araştırma ile modelin farklı teknolojilerin kabulünde de geçerli ve güvenilir olduğu kanıtlanmıştır (Lee, Kozar ve Larsen, 2003; Wang, Lo ve Fang, 2008; Yang, Liu ve Zhou, 2012; Surendran, 2012; Chen, Chen, Chen ve Hsieh, 2012; Tsaur ve Lin, 2018; Ali, Poulova, Akbar, Javed ve Danish, 2020). 
Yapılan araştırmalar bireylerin teknolojileri benimseme nedenlerinin ve onları kullanma niyetinin en iyi tahmin edicisinin TKM olduğunu göstermektedir (Davis ve Venkatesh, 1996: 20). Bu model, algılanan kullanım kolaylığı ve algılanan faydaya dayalı olarak kullanıcı kabulünü tahmin etmek için yaygın olarak kullanılmaktadır (Venkatesh ve Davis, 1996: 451). Teknoloji Kabul Modeli Şekil 1'de sunulmaktadır.

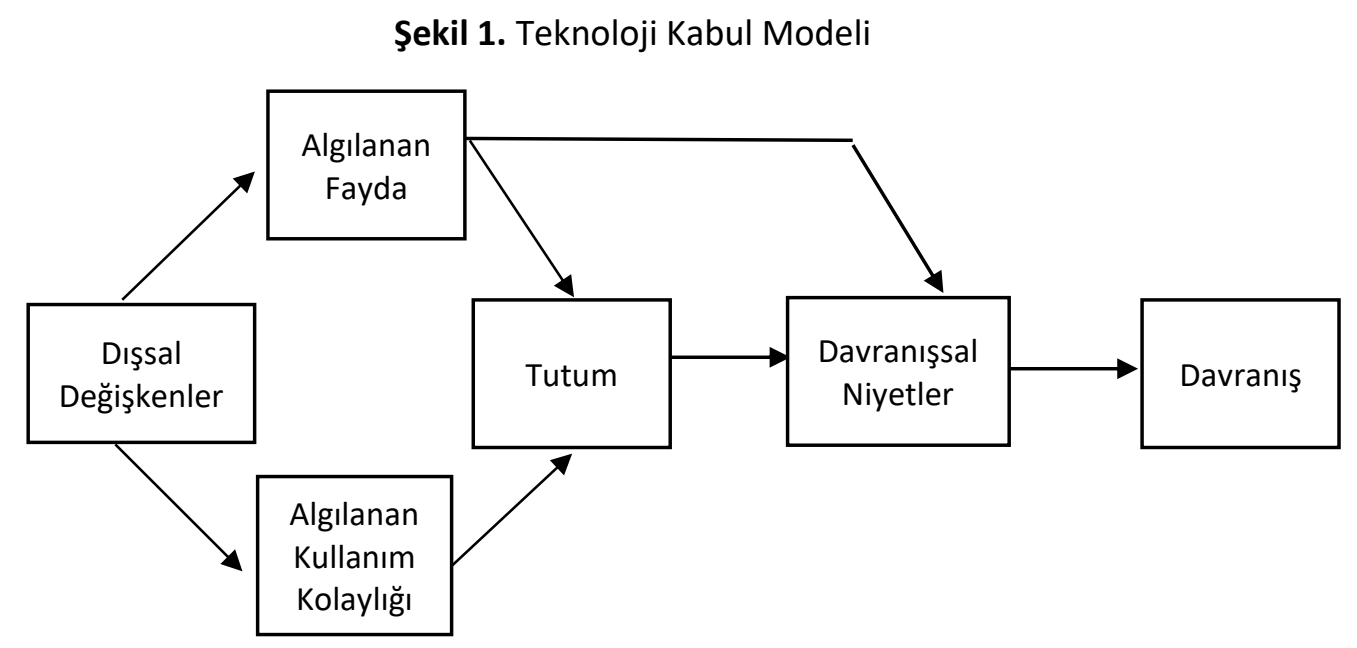

Kaynak: Davis, F. D., Bagozzi, R. P. ve Warshaw, P. R. (1989). User acceptance of computer technology: A comparison of two theoretical models. Management Science, 35(8), 982-1003.

Teknoloji Kabul Modeli, tüketicilerin bir ürünün veya teknolojinin kullanımını kolay algılamaları halinde, onu daha faydalı algılayıp, satın almaya veya kullanmaya yönelik tutum ve dolayısıyla niyet geliştirebileceklerini; bu niyetin ise davranışa dönüşeceğini iddia etmektedir. Buna ek olarak tüketicilerin fayda algılarının artması da hem tutumlarını hem de niyetlerini etkileyecektir. Bu çalışma özelinde Teknoloji Kabul Modeli, algılanan risk ve subjektif norm değişkenleri eklenerek kullanılmıştır.

\subsection{Tutum}

Tüketici davranışı bakış açısıyla tutum, bir ürüne tutarlı bir şekilde yanıt vermek için öğrenme ve deneyimle yaratılan olumlu veya olumsuz bir yatkınlıktır (Moutinho, 1987). Bir ürüne karşı olumlu bir tutum geliştirilmesi, tüketicilerin o ürün hakkında bilgi almasını veya ürünü satın almaya niyetlenmesini sağlamaktadır (Pavlou ve Fygenson, 2006: 118). Bir mal veya hizmetin satın alınması veya alınan ürünün değiştirilmesi süreci, tutum oluşturulması ve tutum değiştirilmesiyle ilişkilidir (Koç, 2019: 293-294).

Tutum, olumlu veya olumsuz biçimde oluşabilir. Bir tutumun oluşabilmesi için tüketicilerin ürünü, başka ürünle mukayese etmesi gerekir. Sonradan öğrenme ile oluşan bu tutum geçici değildir. Bu özellikler göz önüne alındığında, bireyin bir tutum oluşturması için birçok unsura maruz kalması gerekir. Geçici olmayan bu tutumlar, belli bir süre için de olsa kalıcılığını devam ettirir (Durmaz, 2011: 80-81).

\subsection{Niyet}

Arapça kökenli bir sözcük olan "niyet”, Türk Dil Kurumu'nun Türkçe sözlüğünde, "bir şeyi yapmayı önceden isteyip düşünme, maksat" olarak tanımlanmıştır. Bu çalışma özelinde ise "kişilerin doğalgaz kombi cihazı kullanmaya veya satın almaya yönelik geliştirdikleri düşünce" anlamında kullanılmıştır.

TKM kapsamında niyet, davranışın öncülü olarak kabul edilmektedir. Tüketici, satın alma davranışını gerçekleştirmek için ne kadar yüksek bir niyete sahipse, bu davranışı gerçekleştirme olasılığı da o kadar artacaktır. Bu durumda tüketicinin, davranışı gerçekleştirmeye yönelik bir niyet oluşturması için öncelikle o ürünü satın almaya veya kullanmaya yönelik bir tutum oluşturmasının beklendiği söylenebilir. Söz konusu ürün hakkında olumlu tutum geliştiren bir tüketicinin, satın almaya veya kullanmaya yönelik niyetinin de 
olumlu olması beklenir (Ajzen ve Driver, 1991; Öztürk ve Temizkan, 2018). TKM'ye göre bireyin bir sistemi kullanmayı ya da kullanmamayı tercih etmesinde en önemli etken niyettir (Çivici ve Kale, 2007).

\subsection{Algılanan Kullanım Kolaylığı}

Algılanan kullanım kolaylığı, Davis (1989: 320) tarafından, "bir kişinin belirli bir sistemi kullanmanın zahmetsiz olacağına inanma derecesi" olarak tanımlanmıştır. Bu kavram, bir ürünü satın alma kararında oldukça etkilidir. Kişinin ürünü kullanabileceğine dair algısı arttığında, ürünü satın almaya yönelik tutumu da pozitif bir biçimde etkilenecektir (Venkatesh ve Davis, 1996).

TKM, kişilerin oluşturduğu iki özel inancın (algılanan kullanım kolaylığı ve algılanan fayda) bir sistemi kullanmaya yönelik niyetlerini belirlediğini ve bunun sonraki davranışlarıyla bağlantılı olduğunu öne sürer (Venkatesh, 2000: 343). Buradan hareketle bu iki değişkenin TKM için en önemli değişkenlerden olduğunu söylemek mümkündür. Davis (1986: 26)'e göre, algılanan kullanım kolaylığının algılanan fayda ile doğrudan bir bağlantısı vardır. Çünkü kullanımı daha kolay olan bir sistem, kullanıcı için artan bir iş performansı sağlayacaktır. Bu durum sistemin daha faydalı olmasına neden olacaktır.

\subsection{Algılanan Fayda}

Venkatesh (2000: 344) algılanan faydayı "bir kişinin, bir teknolojiyi kullanmasının üretkenliğini artıracağına inanma derecesi" olarak tanımlamıştır. Bireyler bir ürününün kullanışlı olacağına inandıkları ölçüde satın alma ya da almama eğilimindedir. Algılanan fayda, Davis (1986: 25) tarafından ise "bireyin belirli bir sistemi kullanmasının iş performansını arttıracağına inanma derecesi" olarak tanımlanmıştır. Tüketicilerin bir ürüne karşı algıladıkları fayda ne kadar fazlaysa o ürünü satın almaya yönelik oluşturdukları tutumun da o kadar olumlu olacağı söylenebilir (Davis, 1989: 320). Bir ürünün kullanışlı oluşu ve sürdürülebilir avantajlarının olması tüketici tarafından ürünün faydalı olarak algılanmasına neden olur (Moslehpour, Pham, Wong ve Bilgiçli, 2018).

Tüketiciler bir ürünü faydalı gördükleri kadar satın alma eğilimindedir. İşletmeler mal veya hizmetleri geliştirirken, tüketicilerin bekledikleri faydayla, sunulan mal veya hizmetin faydasının örtüşmesi hususuna dikkat etmelidirler. Ürünün kullanımı esnasındaki deneyim, ürünün işlevsel özellikleri gibi unsurlar tüketicilerin algıladıkları faydayı etkileyebilecek unsurlardır. Bir üründen algılanan fayda kişiden kişiye farklılık gösterebileceği için, işletmeler ürünü pazarlamayı hedeflediği kitleye göre ürünün faydasına dikkat çekmelidir (Bilgin Erte, 2020: 39).

\subsection{Algılanan Risk}

Pazarlama disiplini çerçevesinde ilk olarak Raymond Bauer (1960) tarafından kullanılan algılanan risk kavramı, bir mal veya hizmet satın almanın olası olumsuz sonuçlarıyla ilgili hissedilen belirsizlik olarak tanımlanmaktadır (Featherman ve Pavlou, 2003: 453). Assael (1984)'e göre nadiren satın alınan ve görece daha pahalı ürünlerin satın alınmasında tüketicinin risk algısı artacaktır. Daha açık bir ifadeyle; tüketici, ürün hakkında fazla bilgi sahibi değilse ve yanlış bir satın alma sonucunda mali kaybı yüksek olacaksa risk algısı paralel bir şekilde artacaktır (Assael, 1984 aktaran: Mitchell, 1992). Doğalgaz kombi cihazı sık satın alınan bir ürün olmadığı ve maliyeti yüksek olduğu için, tüketiciler bu ürünü satın alma sürecinde yüksek risk algısı hissedebilecektir.

\subsection{Subjektif Norm}

Subjektif normlar, "davranışın tüketicinin etki çemberi tarafından teşvik edilip edilmediğine ve uygulanıp uygulanmadığına dair tüketici algıları" olarak tanımlanabilir (Pavlou ve Fygenson, 2006: 119). Subjektif norm, bireyin referans gruplarının onayına verdiği önemi ve bu grupların ortak inançlarına uyma istekliliğini ölçer (Quintal vd., 2010). Bu gruplar bireyin inançları, tutumları ve seçimleri üzerinde önemli bir etkiye sahiptir (Moutinho, 1987). Subjektif normlar bireyin, bir davranışı gerçekleştirmesi gerekip gerekmediğine dair algısı ve referans gruplarının isteklerine uyma motivasyonunun kombinasyonu olarak düşünülebilir (Sparks, Guthrie ve Shepherd, 1997: 419). Referans gruplarına uymaya yeterince motive olmuş 
bir birey davranışa veya sonuçlarına karşı olumlu düşünceleri olmasa bile davranışı gerçekleştirmeyi seçebilir (Venkatesh ve Davis, 2000: 188). Bu durum bireylerin, önemli gördüğü insanlardan gelen bilgileri kanıt olarak yorumlama eğilimini gösterir (Schepers ve Wetzels, 2007: 91).

Teknoloji Kabul Modeli kullanılan çalışmalarda subjektif norm değişkeni tutarsız sonuçlar vermiştir. Lee ve Wan (2010) yaptıkları çalışmada bulgulardaki bu tutarsızlığı kullanılan örneklemle ilişkilendirmiştir. Bireyci toplumların dahil olduğu örneklemlerde subjektif norm değişkeni etkisiz bulunurken, grup amaçlarının bireysel amaçların önünde olduğu kollektivist toplumların dahil olduğu örneklemlerde subjektif norm değişkeninin göz ardı edilemeyecek bir etkisi olduğu gözlenmiştir. Bu çalışmanın örneklemi kollektivist yönü ağır basan Türkiye'de yaşayan kişiler arasından belirlendiği için, subjektif norm değişkeninin önemli etkiler meydana getireceği düşünülmüş ve çalışma kapsamına dahil edilmiştir.

\section{Literatür ve Hipotezlerin Gerekçelendirilmesi}

Araştırmanın hipotezlerini oluşturmadan önce konuya ilişkin literatürde yer alan çalışmalar incelenmiştir. Bu bağlamda incelenen çalışmalar ve bunlar neticesinde oluşturulan hipotezler araştırmanın bu bölümünde sunulmuştur.

Tsaur ve Lin (2018), güneş enerji panellerinin Tayvan halkı tarafından kabulünü ölçmek amacıyla TKM kapsamında bir araştırma yapmışlardır. Elde edilen bulgular, tüketicilerin güneş enerji panellerinin kullanımını kolay olarak algılamalarının, panel kullanımına yönelik tutum oluşturmalarını sağladığını göstermektedir. Hua ve Wang (2019) ise yaptıkları çalışmada, TKM ve Planlı Davranış Teorisi (PDT)'nin değişkenlerini kullanarak oluşturdukları model ile tüketicilerin enerji tasarruflu cihazları satın alma niyetlerini ölçmek istemişlerdir. 280 katılımcıdan toplanan veriler üzerinde yapılan analizler sonucunda tüketicilerin enerji tasarruflu cihazlar hakkında algıladıkları kullanım kolaylığının, satın almaya yönelik tutumlarını etkilediği sonucuna ulaşılmıştır. Benzer bir araştırmada, Pakistan'da yaşayan tüketicilerin güneş enerji panellerini satın alma niyetlerini ölçmek amacıyla TKM çerçevesinde bir saha çalışması yapılmıştır. Katılımcılardan toplanan 435 anketle yapılan analizler sonucunda Pakistan'da yaşayan tüketicilerin güneş enerji sistemlerinin kullanımını kolay algılamalarının, satın almaya yönelik tutum oluşturmalarına yol açtığı gözlenmiştir (Ali vd., 2020).

Geçmiş araştırma sonuçlarından yola çıkılarak tüketicilerin doğalgaz kombi cihazlarının kullanımını kolay olarak algılamalarının satın almaya yönelik tutum oluşturmalarına olan etkisinin bu çalışma özelinde yeniden test edilmesi uygun görülmüştür. Buradan hareketle $\mathrm{H}_{1}$ hipotezi oluşturulmuştur.

$\mathbf{H}_{1}$ : Tüketicilerin doğalgaz kombi cihazlarından algıladıkları kullanım kolaylığı, satın almaya yönelik tutumu pozitif ve anlamlı bir biçimde etkiler.

Shih (2004) yaptığı çalışmada, PDT ve TKM'nin ortak paydasında bir model geliştirip tüketicilerin internet alışverişini kabul etme niyetini ölçmeyi amaçlamıştır. Bu doğrultuda 212 katılımcıdan anket yöntemi ile veriler toplanmıştır. Araştırma sonucunda, tüketicilerin internet alışverişine yönelik tutumlarının bu işlemden fayda sağlayacağını düşündüklerinde arttığı anlaşıımıştır. Bir diğer çalışmada ise, kullanıcıların enerji yönetim sistemini benimserken fayda algılaması durumunda, sistemi kullanmaya yönelik tutum oluşturacakları sonucuna ulaşılmıştır (Chin ve Lin, 2015). Kardooni, Yusoff ve Kari (2016) ise yaptıkları çalışmada, Malezyalı tüketicilerin yenilenebilir enerjiyi kabul etmesini etkileyen faktörleri incelemeyi amaçlamışlardır. Tabakalı örnekleme yöntemi ile ülkenin farklı bölgelerinden veriler toplanmış ve Malezya nüfusunun \%21,75'i ile görüşme sağlanmıştır. Elde edilen bulgular değerlendirildiğinde, tüketicilerin yenilenebilir enerjiden fayda algılamaları halinde, kullanmaya yönelik tutum oluşturacakları sonucu ortaya çıkmıştır. Li ve Wang (2019)'ın tüketicilerin enerji verimli cihazları kabul etmesinin öncüllerini belirlemek amacıyla yürüttükleri çalışmada ise algılanan faydanın tutum üzerinde önemli bir etkisi olduğu gözlenmiştir.

Literatür taraması sonucunda elde edilen bulgulardan yola çıkılarak algılanan fayda değişkeninin, tutum değişkeni üzerindeki etkisinin, Türkiye'den bir örneklemle yeniden test edilmesinin literatüre katkı sağlayacağı düşünülmüştür. Buradan hareketle $\mathrm{H}_{2}$ hipotezi geliştirilmiştir.

$\mathbf{H}_{2}$ : Tüketicilerin doğalgaz kombi cihazlarından algıladıkları fayda, satın almaya yönelik tutumu pozitif ve anlamlı bir biçimde etkiler. 
Chen vd. (2012), Tayvan'da tüketicilerin elektrikli motosiklet satın alma niyetlerini araştırdıkları bir çalışma yapmışlardır. Çalışma sonucunda tüketicilerin satın almaya yönelik tutumlarının, algılanan risk kavramıyla önemli ölçüde ilgili olduğu sonucuna ulaşılmıştır. TKM'ne algılanan risk değişkeni eklenerek oluşturulan bir modeli test etmek üzere yürütülen bir diğer çalışmada, internet bankacılığı hizmetinden algılanan riskin, bu ürüne yönelik tutum ve niyet üzerinde negatif etkileri tespit edilmiştir (Ceylan, Genç ve Erem, 2013). Wu ve Chen (2014) tarafından PDT'nin genişletilmiş bir modeli kullanılarak, tüketicilerin yeşil (çevre dostu) tüketim ürünlerini satın alma niyetinin incelendiği bir araştırma sonucunda ise, tüketicilerin ürün hakkında risk algısının oluşmasının satın almaya yönelik tutumlarını etkilediği tespit edilmiştir. Han, Yu ve Kim (2019) ise yaptıkları çalışmada, müşterilerin elektrikli uçakları benimseme düzeylerini ve bu tür elektrikli uçak uçuşları için geleneksel uçuş fiyatlarını ödemeye hazır olup olmadıklarını araştırmışlardır. Araştırma çevrimiçi anket yöntemi ile son bir yıl içinde havayolu kullanarak seyahat etmiş kişiler üzerinde uygulanmıştır. Yargısal örnekleme yöntemiyle seçilen katılımcılardan toplanan 321 anketin analizi sonucunda, müşterilerin risk algısının elektrikli uçakları benimsemeye yönelik tutumlarını negatif ve anlamlı bir biçimde etkilediği gözlenmiştir.

Doğalgaz kombi cihazlarının, kolayda ürünlere göre daha nadir satın alınan özellikli ürünler olmasından dolayı tüketicilerin risk algısının bu çalışma özelinde yüksek olacağı düşünülmüştür. Bu nedenle $\mathrm{H}_{3}$ hipotezinin test edilmesine karar verilmiştir.

$\mathrm{H}_{3}$ : Tüketicilerin doğalgaz kombi cihazlarından algıladıkları risk, satın almaya yönelik tutumlarını negatif ve anlamlı bir biçimde etkiler.

Yaghoubi vd. (2010), İran'da bulunan küçük ve orta ölçekli işletmeler üzerinde (KOBi) bir çalışma yürütmüşlerdir. Söz konusu çalışmada KOBI'lerin e-ticareti benimsemesini etkileyen faktörlerin belirlenmesi amaçlanmıştır. Bu amaçla, 83 işletme ile görüşme sağlayan yazarlar, PDT ve TKM 2 doğrultusunda bir model oluşturmuştur. Yapılan analizler sonucunda elde edilen bulgular incelendiğinde, işletmelerin e-ticareti benimsemesinde subjektif normların algılanan fayda ve tutumları etkilediği gözlenmiştir. Yang vd. (2012) ise Çinli tüketicilerin mobil viral tutumlarını, niyetlerini ve davranışlarını ölçmek amacıyla yaptıkları çalışmada, PDT ve TKM'nin birleşimi olan bir model geliştirip söz konusu modele yeni değişkenler eklemişlerdir. Yapılan analizler sonucunda tüketicilerin subjektif norm düzeylerinin viral tutum ve niyetler üzerinde anlamlı bir etkisi olduğu gözlenmiştir. Çelik ve İpçioğlu (2014), öğrencilerin interneti benimseme davranışlarını tahmin etmek için, teknoloji kabulüyle ilgili teorilerin birleşiminden oluşan yapısal bir modelin geliştirilmesi amacıyla bir çalışma yapmıştır. Çalışma sonucunda, subjektif norm değişkeninin, algılanan fayda değişkeni üzerinde beklenen etkisi doğrulanmıştır. Benzer bir araştırmada, Erciş ve Aydın (2015) mobil viral iletişimde tutum, niyet ve davranışlara etki eden unsurların ölçülmesini amaçlamışlardır. Araştırma bulguları değerlendirildiğinde, subjektif norm değişkeninin viral tutumlar üzerinde etkili olduğu sonucuna ulaşılmıştır. Köylüoğlu, Acar ve İnan (2018) ise yaptıkları çalışmada, çevre dostu otomobillere yönelik satın alma davranışlarını incelemeyi amaçlamışlardır. Elde edilen bulgulara göre; subjektif normlar, çevre dostu otomobillere yönelik oluşturulan tutumları pozitif ve anlamlı bir biçimde etkilemektedir. Bir diğer çalışmada, Paramaeswari ve Sarno (2020) Shopee, Tokopedia ve Bukalapak adlı üç e-ticaret sitesinin kullanıcılarının ilgisini etkileyen faktörleri belirlemek için karşılaştırmalı bir analiz yapmışlardır. Kullanıcıların e-ticaret sitelerinin kullanımının referans grupları tarafından önerilmesi halinde fayda algısııın artacağına yönelik oluşturulan hipotezlerden Bukalapak sitesi için olan kabul edilirken; diğer e-ticaret sitelerine yönelik hazırlanan hipotezler reddedilmiştir.

Subjektif norm değişkeninin algılanan fayda ve tutum değişkenleri üzerindeki etkisinin doğalgaz kombi cihazının satın alınma sürecinde geçerli olup olmadığını incelemenin yararlı olacağı düşünülmüştür. Bu doğrultuda $\mathrm{H}_{4}$ ve $\mathrm{H}_{5}$ hipotezlerinin test edilmesine karar verilmiştir.

$\mathrm{H}_{4}$ : Tüketicilerin doğalgaz kombi cihazlarına yönelik subjektif norm düzeyleri, satın almaya yönelik tutumlarını pozitif ve anlamlı bir biçimde etkiler.

$\mathbf{H}_{5}$ : Tüketicilerin doğalgaz kombi cihazlarına yönelik subjektif norm düzeyleri, fayda algısını pozitif ve anlamlı bir biçimde etkiler. 
Wang vd. (2008) yaptıkları çalışmada, müşterilerin Multimedya Mesajlaşma Servisleri (MMS) teknolojisini kabulünü incelemiştir. Çalışma, TKM'nin genişletilmiş bir versiyonu ile yürütülmüştür. Araştırma sonucunda, tüketicilerin bu teknolojide kullanım kolaylığı algılaması halinde fayda algılarının da arttığı gözlenmiştir. Bu genişletilmiş modele göre tüketiciler, MMS teknolojisini kabul etmeden önce algılanan kullanım kolaylığı ve algılanan faydayı dikkate almıştır. E-alışverişin tüketici kabulünü anlamak amacıyla yürütülen bir araştırmada ise, tüketicilerin e-alışverişin kullanımını kolay olarak algılaması durumunda faydalı olarak da görecekleri sonucuna ulaşımıştır (Ha ve Stoel, 2009). Karimzadeh ve Salehi (2021) tüketicilerin güneş enerji panellerini hanelerinde kullanma niyetini ölçmek amacıyla yaptıkları çalışmada, tüketicilerin kullanım kolaylığı algılarının, ürünü faydalı görmelerine sebebiyet verdiği sonucuna ulaşmışlardır. Hua ve Wang (2019) tarafından tüketicilerin enerji tasarruflu cihazları satın alma niyetinin belirleyicilerini ortaya koymak amacıyla yürütülen bir başka çalışmada ise, tüketicilerin bu cihazların kullanımında kolaylık algılaması halinde, bunları daha faydalı ve kullanışlı olarak görecekleri sonucuna ulaşılmıştır.

Algılanan kullanım kolaylığı ve algılanan fayda değişkenleri arasındaki ilişkiye yönelik literatür araştırması sonucunda, bu ilişkinin -tüketicilerin kombi tercihlerindeki etkisini görmek amacıyla- test edilmesinin faydalı olacağına karar verilmiştir. Bu doğrultuda $\mathrm{H}_{6}$ hipotezi geliştirilmiştir.

$\mathbf{H}_{6}$ : Tüketicilerin doğalgaz kombi cihazlarından algıladıkları kullanım kolaylığı, fayda algısını pozitif ve anlamlı bir biçimde etkiler.

Maichum, Parichatnon ve Peng (2016) Taylandlı tüketicilerin çevre dostu (yeşil) ürünleri satın alma niyetini PDT çerçevesinde inceledikleri çalışmalarının sonucunda, tüketicilerin olumlu tutum geliştirmelerinin, çevre dostu ürünleri satın almaya yönelik niyet oluşturmalarında güçlü bir etkiye sahip olduğunu ortaya koymuşlardır. Yadav ve Pathak (2016) ise yaptıkları çalışmada, genç tüketicilerin çevre dostu ürün satın alma niyetlerini, gelişmekte olan bir ülke olan Hindistan'da incelemek amacıyla PDT'ni genişleterek bir model oluşturmuştur. 326 tüketiciden anket yöntemiyle toplanan verilerin analizi sonucunda, Hindistan'da ikamet eden genç tüketicilerin çevre dostu ürün satın almaya yönelik oluşturdukları tutumların, satın alma niyeti üzerinde pozitif ve anlamlı bir etkisi olduğu anlaşılmıştır. Suki (2016) tarafından yapılan bir başka çalışmada, tüketicilerin yeşil markalara karşı tutumları ve yeşil markalı ürünleri satın alma niyetleri incelenmiştir. Araştırma sonucunda, tüketicilerin yeşil markalara yönelik oluşturdukları tutumların, yeşil markalı ürünleri satın almaya yönelik niyet oluşumunu etkilediği ortaya konmuştur. Benzer biçimde, Tan, Ooi ve Goh (2017) tarafından yapılan bir araştırmada, Malezya'da yaşayan tüketicilerin enerji verimli ev aletlerine yönelik tutumlarının, satın alma niyetlerini pozitif ve anlamlı bir biçimde etkilediği sonucuna ulaşılmıştır. Kartawinata, Maharani, Pradana ve Amani (2020) ise yaptıkları çalışmada, çevreye zarar vermeyen, ekolojik ürünler sunan Love, Beauty and Planet isimli markaya karşı tüketicilerin tutumlarını incelemişlerdir. Söz konusu markanın tüketicilerinden oluşan 150 kişilik bir gruptan toplanan verilerin analizi sonucunda, tüketicilerin çevre dostu markaya yönelik olumlu tutum geliştirmelerinin, satın alma niyetlerini pozitif ve anlamlı bir biçimde etkilediği sonucuna ulaşılmıştır.

Tüketici tutumlarının satın alma niyeti üzerindeki etkisi, yukarıdaki çalışmalarla ve literatürdeki pek çok başka araştırmayla ortaya konmuştur. Doğalgaz kombi cihazı özelinde bu değişkenler arasındaki etkileşimin test edilmesinin literatüre katkı sunacağı düşünülmektedir. Buradan hareketle $\mathrm{H}_{7}$ hipotezi oluşturulmuştur.

$\mathrm{H}_{7}$ : Tüketicilerin doğalgaz kombi cihazlarına yönelik tutumları, satın alma niyetlerini pozitif ve anlamlı bir biçimde etkiler.

\section{Yöntem}

Bu bölümde yapılan literatür çalışması sonucunda oluşturulan araştırmanın hipotezleri, araştırmanın modeli, araştırmanın ana kütlesi, anket formunun hazırlanması, anket formunda kullanılan ölçekler ve verilerin analizi anlatılmaktadır. 


\subsection{Araştırmanın Amacı ve Modeli}

$\mathrm{Bu}$ araştırmanın amacı, tüketicilerin kombi tercihlerini etkileyen faktörleri, TKM çerçevesinde incelemektir. Bu bağlamda tüketicilerin kombi tercihlerinde algılanan kullanım kolaylığı ve algılanan fayda değişkenlerinin tutumlarını; tutumlarının ise niyetlerini nasıl etkilediğini görmek amacıyla bir model oluşturulmuştur. Ayrıca tüketicilerin tutumlarını etkilediği düşünülen, algılanan risk ve subjektif norm değişkenleri model kapsamına dahil edilmiştir. Söz konusu model Şekil 2'de gösterilmektedir.

Şekil 2. Araştırmanın Teorik Modeli

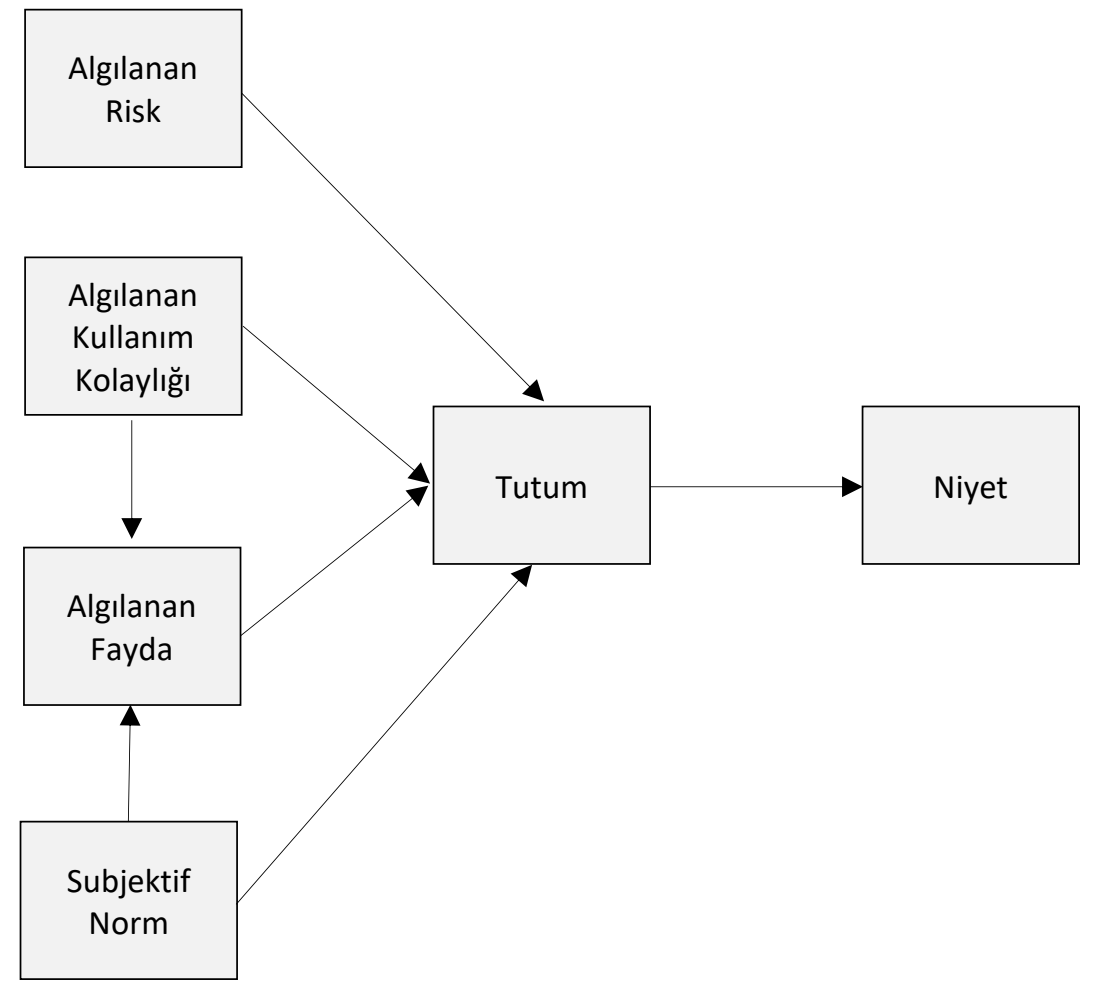

\subsection{Araştırmanın Evreni ve Örneklem}

Araştırmanın ana kütlesini Türkiye' de son bir yıl içerisinde doğalgaz kombi cihazı satın alan tüketiciler oluşturmaktadır. Ana kütlenin bu şekilde belirlenmesinin nedeni, bu tüketicilerin doğalgaz kombi cihazını satın alarak bu tecrübeyi kısa zaman önce yaşamış ve bu teknoloji hakkında belirli bir bilgi düzeyine sahip olan kişiler olmasıdır. Araştırma, bu ana kütleden yargısal örnekleme yöntemiyle belirlenen 394 tüketici üzerinde Nisan 2021-Haziran 2021 tarihleri arasında çevrimiçi anket yöntemiyle toplanan verilerle yürütülmüştür. Yargısal örnekleme, "katılımcının sahip olduğu nitelikler nedeniyle kasıtlı olarak seçilmesi" olarak tanımlanabilir (Etikan, Musa ve Alkassim, 2016). Perla ve Provost (2012)'a göre ulaşılmak istenen kitlenin, belirli bir süreç veya sistem hakkında bilgi sahibi olmasının istendiği durumlarda, yargısal örneklemeyi kullanmak doğru olacaktır. Bu araştırma özelinde, ana kütlenin doğalgaz kombi cihazını yeni satın almış ve süreç hakkında bilgisi olan kişilerden oluşması istendiğinden, yargısal örnekleme yönteminin kullanılması uygun görülmüştür. Anket formları içerisinden "Son bir yılda doğalgaz kombi cihazı satın aldınız mı?" sorusuna "hayır" cevabı verilen, eksik ya da hatalı doldurulan ve soruların tümünde veya büyük bir kısmında aynı seçenekler işaretlendiğinden dolayı okunmadığı anlaşılan 127 form analiz kapsamı dışında bırakılmıştır. Toplam 267 anket ile analizler yürütülmüştür. 


\subsection{Anket Formunun Hazırlanma Süreci ve Kullanılan Ölçekler}

Araştırma kapsamında kullanılacak ölçekleri belirlemek amacıyla kapsamlı bir literatür araştırması yapılmıştır. Yapılan literatür incelemesi doğrultusunda çeşitli çalışmalardan alınan güvenilirliği ve geçerliliği kanıtlanmış ölçekler, söz konusu bu çalışmaya uygun olacak biçimde uyarlanmış olup, anket formu çevrimiçi olarak hazırlanmıştır. Çalışmada kullanılan anket formunun ve toplanan verilerin etik açıdan uygunluğu Balıkesir Üniversitesi Sosyal ve Beşeri Bilimler Etik Komisyonunun 23.09.2021 tarih ve 2021/04 sayılı toplantısında onaylanmıştır.

Hazırlanan anket formu toplam üç bölümden oluşmaktadır. Birinci bölümde öncelikle katılımcılara "Evinizde doğalgaz kombi ile mi ısınıyorsunuz?" ve "Son bir yılda doğalgaz kombi cihazı satın aldınız mı?" soruları yöneltilmiştir. Olumsuz yanıt veren katılımcıların anketi sonlandırılmıştır. İkinci bölümde katılımcıların demografik yapısını ortaya koymaya yönelik sorular bulunmaktadır. Üçüncü bölümde araştırma modelinde yer alan değişkenlere ilişkin ifadeler yer almaktadır. Hazırlanan çevrimiçi ankette araştırmanın modelini test etmek için kullanılan ifadelerin değerlendirilmesinde beşli Likert tipi değerlendirme ölçeği kullanılmıştır.

Araştırma kapsamında kullanılan niyet değişkenini ölçmeye yönelik ifadeler, Taylor ve Todd (1995), Zeithaml, Berry ve Parasuraman (1996) ve Venkatesh ve Davis (2000)'in çalışmalarından alınan yedi ifadeden oluşmaktadır. Tutum değişkeni anket formunda beş soruyla ölçülmüş olup, değişkene ilişkin ifadeler Taylor ve Todd (1995) ve Lee (2009)'nin çalışmalarından uyarlanmıştır. Algılanan risk değişkenini ölçmek için Wu ve Wang (2005)'ın çalışmasında bulunan beş soruluk ölçekten yararlanılmıştır. Bununla birlikte, bu ifadelerin algılanan risk kavramını tüm boyutlarıyla kapsamadığı düşünüldüğü için yazarlar tarafından oluşturulan iki soru ölçeğe eklenmiştir. Algılanan kullanım kolaylığı ile ilgili üç soru için Venkatesh ve Davis (1996)'in çalışmasından yararlanılmıştır. Subjektif norm değişkeni anket formunda üç ifadeyle ölçülmüş olup, ilgili ifadeler Lee (2009)'nin çalışmasından uyarlanmıştır. Algılanan fayda değişkeni ise üç soruyla ölçülmüş olup, soruların oluşturulmasında Joo ve Sang (2013)'ın çalışmasından yararlanılımıştır.

\section{Bulgular}

\subsection{Betimleyici İstatistikler}

Katılımcılara iliş̧in demografik özelliklerin sunulduğu Tablo 1 incelendiğinde, cevaplayıcıların \%56,9'unun erkek olduğu gözlenmiştir. Bunun yanı sıra katılımcıların \%50,6'sı bekardır. Katılımcıların yarısından fazlasını $(\% 53,2)$ üniversite mezunları oluşturmaktadır. Buna ek olarak bu kişilerin yaş ortalaması 37,16 ve aylık hane halkı toplam gelirlerinin ortalaması 7.169,36 $\ddagger^{\prime}$ dir.

Tablo 1. Katılımcılara Iliş̧in Demografik Bulgular

\begin{tabular}{|l|c|c|c|}
\hline \multicolumn{2}{|c|}{} & Frekans & Yüzde \\
\hline \multirow{3}{*}{ Cinsiyet } & Kadın & 115 & $\% 43,1$ \\
\cline { 2 - 4 } & Erkek & 152 & $\% 56,9$ \\
\cline { 2 - 4 } & Toplam & 267 & $\% 100$ \\
\hline \multirow{3}{*}{ Medeni Durum } & Evli & 132 & $\% 49,4$ \\
\cline { 2 - 4 } & Bekar & 135 & $\% 50,6$ \\
\cline { 2 - 4 } & Toplam & 267 & $\% 100$ \\
\hline \multirow{3}{*}{ Eğitim Durumu } & Ilk ve Ortaokul & 17 & $\% 6,4$ \\
\cline { 2 - 4 } & Lise & 142 & $\% 24,3$ \\
\cline { 2 - 4 } & Üniversite & 43 & $\% 53,2$ \\
\cline { 2 - 4 } & Yüksek & 267 & $\% 16,1$ \\
\cline { 2 - 4 } & Lisan $/$ Doktora & 37,16 & $\% 100$ \\
\hline Yaş Ortalaması & Toplam & $7.169,36 も$ & \\
\hline Gelir Ortalaması & \multicolumn{2}{|c|}{} \\
\hline
\end{tabular}




\subsection{Araştırmanın Değişkenlerine İlişkin Tanımlayıcı İstatistikler}

Araştırmanın değişkenlerine ilişkin aritmetik ortalama ve standart sapma değerleri Tablo 2'de sunulmuştur. Buna göre, en yüksek aritmetik ortalama değeri 4,60 ile algılanan kullanım kolaylığı değişkenine aittir. Bunu sırasıyla tutum $(4,40)$; niyet $(4,39)$; subjektif norm $(3,75)$ ve algılanan risk $(2,54)$ değişkenleri izlemektedir. Bu bulgular, katılımcıların doğalgaz kombi cihazlarının kullanımını kolay algıladıklarını ve satın almaya yönelik tutum ve niyet oluşturduklarını göstermektedir. Buna ek olarak katılımcıların, doğalgaz kombi cihazını satın alırken onlar için önemli olan kişi veya grupların önerilerini dikkate aldığını ve bu süreçte risk algılarının nispeten yüksek olduğunu -risk ifadeleri ters yönlü (reverse) olduğu için- söylemek mümkündür.

Tablo 2. Araştırmanın Ana Değişkenlerine iliş̧kin İstatistikler

\begin{tabular}{|c|c|c|c|c|c|c|}
\hline & T & N & AKK & AFA & SN & AR \\
\hline Aritmetik Ortalama & 4,40 & 4,39 & 4,60 & 4,33 & 3,75 & 2,54 \\
\hline Standart Sapma & 0,75 & 0,74 & 0,62 & 0,86 & 1,28 & 1,02 \\
\hline
\end{tabular}

T: Tutum; N: Niyet; AKK: Algılanan Kullanım Kolaylığı; AFA: Algılanan Fayda; AR: Algılanan Risk; SN: Subjektif Norm.

\subsection{Güvenilirlik ve Geçerlilik Analizleri}

Araştırmanın bu bölümünde verilerin güvenilirliğini ve ölçeklerin geçerliliğini ortaya koymak amacıyla yapılan keşifsel faktör analizi ve doğrulayıcı faktör analizi bulgularına yer verilmiştir. Bunlara ek olarak güvenilirlik ve geçerlilik için önemli birer kanıt olarak görülen AVE ve CR değerleri ile Cronbach $\alpha$ katsayıları sunulmuştur.

Keşifsel faktör analizi SPSS 26 paket programı kullanılarak temel bileşenler analizi yöntemiyle yapılmıştır. Bu analizin yapılmasının nedeni, anket formunda yer alan ifadelerin hangi temel bileşenlere işaret ettiğini belirlemek ve böylelikle uygun bileşik değişkenler oluşturarak bulguların sunumunu kolaylaştırmaktır. Faktörlerin belirlenmesinde rotasyon yöntemi olarak varimax kullanılmıştır. Keşifsel faktör analizine başlanmadan önce, örneklem yeterliliğini ölçebilmek ve verilerin faktör analizine uygun olup olmadığını belirlemek için KMO (Kaiser-Meyer-Olkin) ve Bartlett'ın küresellik testi sonuçları incelenmiştir. İslamoğlu ve Alnıaçık (2016) tarafından, KMO değerinin 0,60 ve üzerinde bir değer alması, Bartlett testinin ise anlamlı olması önerilmektedir. Bu çalışmada KMO değeri 0,876 olarak hesaplanırken, Bartlett testi 0,01 düzeyinde anlamlı bulunmuştur.

Tablo 3'te analiz bulguları yer almaktadır. Keşifsel faktör analizi sonucunda, niyet değişkeninden iki, algılanan risk değişkeninden iki olmak üzere dört ifade faktör yüklerinin düşük olması ve farklı faktörlere yüklenmeleri nedeniyle analiz kapsamından çıkarılmıştır. Bulgular incelendiğinde kalan 24 ifadenin değişkenlere uygun şekilde yüklendiği gözlenmektedir. Altı alt boyuta yerleşen ifadelerin toplam açıkladığı varyans \%77,081 olarak bulunmuştur. Bu değerin sosyal bilimlerde en az \%60 olması istenmektedir (Nakip, 2006: 432).

Araştırmada kullanılan ifadelerin farklı kaynaklardan alınması ve daha önce Türkçeye uyarlanmamış olmaları sebebiyle keşifsel faktör analizi ile beraber doğrulayıcı faktör analizinin de yapılması gerekmektedir. Doğrulayıcı faktör analizi (DFA), önceden belirlenmiş bir yapının doğrulanması amacıyla yapılır. DFA ile belirlenen faktörler arasındaki ilişkinin yeterli olup olmadığı ve faktörlerin modeli açıklamada ne kadar başarılı olduğu sınanır (Erkorkmaz, Etikan, Demir, Özdamar ve Sanisoğlu, 2013; Yaşlıoğlu, 2017). Bu çalışmada DFA için AMOS 24 paket programı kullanılmıştır. 
Tablo 3. Keşifsel Faktör Analizi Bulguları

\begin{tabular}{|c|c|c|c|c|c|c|}
\hline & 1 & 2 & 3 & 4 & 5 & 6 \\
\hline \multicolumn{7}{|l|}{ Tutum } \\
\hline Bu kombiyi satın almak istediğim bir şeydi. & 0,812 & & & & & \\
\hline Bu kombiye karşı olumlu bir tutum içerisindeyim. & 0,805 & & & & & \\
\hline Bu kombiyi satın almak iyi bir fikirdi. & 0,787 & & & & & \\
\hline $\begin{array}{l}\text { Bu kombiyi satın almış olmak benim için mutluluk } \\
\text { vericidir. }\end{array}$ & 0,776 & & & & & \\
\hline $\begin{array}{l}\text { Bu kombiyi satın almanın genel yakıt maliyetini azaltması } \\
\text { bakımından doğru bir karar olduğunu düşünüyorum. }\end{array}$ & 0,757 & & & & & \\
\hline \multicolumn{7}{|l|}{ Niyet } \\
\hline Aynı kombi markasının müşterisi olmayı sürdüreceğim. & & 0,860 & & & & \\
\hline Her zaman ilk tercihim bu kombi markası olacaktır. & & 0,834 & & & & \\
\hline $\begin{array}{l}\text { Benim önerilerimi isteyen arkadaşlarıma kullandığım } \\
\text { kombiyi tavsiye ederim. }\end{array}$ & & 0,744 & & & & \\
\hline $\begin{array}{l}\text { Satın aldığım kombi markasını tanıdıklarıma tavsiye } \\
\text { edebilirim. }\end{array}$ & & 0,676 & & & & \\
\hline $\begin{array}{l}\text { Gelecekte ısınma ihtiyacımı bu kombi ile karşılamayı } \\
\text { düşünüyorum. }\end{array}$ & & 0,621 & & & & \\
\hline \multicolumn{7}{|l|}{ Algılanan Risk } \\
\hline $\begin{array}{l}\text { Kombi kullanmanın can güvenliği açısından riskli } \\
\text { olduğunu düşünüyorum. }\end{array}$ & & & 0,804 & & & \\
\hline $\begin{array}{l}\text { Aldığım kombiden dolayı mutsuz olma ihtimali beni } \\
\text { düşündürüyor. }\end{array}$ & & & 0,799 & & & \\
\hline $\begin{array}{l}\text { Kombi alırken anlatılan performans özelliklerinin } \\
\text { gerçekleşmeme riski beni endişelendiriyor. }\end{array}$ & & & 0,780 & & & \\
\hline Kombinin arızalanma ihtimali beni düşündürüyor. & & & 0,774 & & & \\
\hline $\begin{array}{l}\text { Aldığım kombiden dolayı çevremdekiler tarafından } \\
\text { eleştirilme riski beni endişelendiriyor. }\end{array}$ & & & 0,704 & & & \\
\hline \multicolumn{7}{|l|}{ Subjektif Norm } \\
\hline Benim için değerli olan kişiler bu kombiyi almamı önerdi. & & & & 0,937 & & \\
\hline Kararlarımda etkili olan kişiler bu kombiyi almamı önerdi. & & & & 0,934 & & \\
\hline $\begin{array}{l}\text { Fikirleri benim için önemli olan kişiler bu kombiyi almamı } \\
\text { önerdi. }\end{array}$ & & & & 0,915 & & \\
\hline \multicolumn{7}{|l|}{ Algılanan Kullanım Kolaylığı } \\
\hline $\begin{array}{l}\text { Kombi kullanmayı kolayca başarabileceğimi } \\
\text { düşünüyorum. }\end{array}$ & & & & & 0,859 & \\
\hline $\begin{array}{l}\text { Aldığım kombiyi kullanmayı kolayca öğrenebileceğimi } \\
\text { düşünüyorum. }\end{array}$ & & & & & 0,850 & \\
\hline Aldığım kombiyi kullanmak kolaydır. & & & & & 0,824 & \\
\hline \multicolumn{7}{|l|}{ Algılanan Fayda } \\
\hline $\begin{array}{l}\text { Kombi kullanmak genel ısınma maliyetimin azalmasına } \\
\text { olanak sağlar. }\end{array}$ & & & & & & 0,861 \\
\hline $\begin{array}{l}\text { Kombi kullanmak diğer ısınma yöntemlerine göre daha } \\
\text { avantajlıdır. }\end{array}$ & & & & & & 0,840 \\
\hline $\begin{array}{l}\text { Genel olarak kombi ile ısınmak diğer sistemlerden daha } \\
\text { yararlıdır. }\end{array}$ & & & & & & 0,766 \\
\hline ÖZ DEĞER & 3,841 & 3,544 & 3,200 & 2,746 & 2,672 & 2,495 \\
\hline AÇIKLANAN VARYANS (\%) & 16,006 & 14,766 & 13,334 & 11,443 & 11,135 & 10,398 \\
\hline TOPLAM AÇIKLANAN VARYANS (\%) & \multicolumn{6}{|c|}{77,081} \\
\hline
\end{tabular}


Tablo 4'te yer alan veriler incelendiğinde $\chi^{2} /$ sd ve standartlaştırılmış ortalama hataların karekökü (standardized root mean square residual-SRMR) değerlerinin iyi uyum; karşılaştırmalı uyum endeksi (comperative fit index-CFI) ve yaklaşık hataların ortalama karekökü (root mean square error of approximation-RMSEA) değerlerinin kabul edilebilir uyum aralığında olduğu gözlenmektedir. Düzeltilmiş uyum iyiliği endeksi (adjusted goodness of fit index-AGFI) değeri, eşik değerin bir miktar altında kalmış olsa da diğer uyum iyiliği değerleri incelendiğinde DFA modelinin kabul edilebilir düzeyde uyum gösterdiği ve faktör yapısının doğrulandığı söylenebilir.

Tablo 4. Doğrulayıcı Faktör Analizi Uyum İyiliği İstatistikleri

\begin{tabular}{|c|c|c|c|}
\hline $\begin{array}{c}\text { Uyum } \\
\text { Ölçüleri }\end{array}$ & Iyi Uyum & Kabul Edilebilir Uyum & $\begin{array}{c}\text { Gözlenen } \\
\text { Değer }\end{array}$ \\
\hline$\chi^{2} / s d$ & $0 \leq \chi^{2} /$ sd $\leq 2$ & $2<\chi^{2} /$ sd $\leq 3$ & 1,943 \\
\hline SRMR & $0 \leq$ SRMR $\leq 0,05$ & $0,05 \leq$ SRMR $\leq 0,10$ & 0,0476 \\
\hline AGFI & $0,90 \leq \mathrm{AGFI} \leq 1,00$ & $0,85 \leq \mathrm{AGFI} \leq 0,90$ & 0,847 \\
\hline CFI & $0,97 \leq \mathrm{CFI} \leq 1,00$ & $0,95 \leq \mathrm{CFI} \leq 0,97$ & 0,954 \\
\hline RMSEA & $0 \leq$ RMSEA $\leq 0,05$ & $0,05 \leq \mathrm{RMSEA} \leq 0,08$ & 0,060 \\
\hline
\end{tabular}

Kaynak: Bayram, N. (2010). Yapısal eşitlik modellemesine giriş: AMOS uygulamaları (1. Baskı). Bursa: Ezgi Kitabevi.

Araştırmada kullanılan ifadelerin güvenilirliğini ölçmek amacıyla 24 ifadenin tümünün birlikte analiz edilmesiyle ortaya çıkan Cronbach $\alpha$ katsayısı 0,832'dir. Cronbach $\alpha$ katsayısının 0,70'in üzerinde olması örneklemin iç tutarlılığının ve güvenilirliğinin yüksek olduğunu göstermektedir (Nakip, 2006). Tablo 5 'te ise her bir boyuta ilişkin Cronbach $\alpha$ katsayıları gösterilmektedir. Bulgular incelendiğinde, bütün değişkenlerin güvenilirliğinin yüksek olduğu söylenebilir.

Yakınsama geçerliliği için maddelerin faktör yükleri ile her bir boyutun açıklanan ortalama varyans (average variance extracted - AVE) ve birleşik güvenilirlik (composite reliability - CR) değerleri incelenmektedir. Hair vd. (2014: 618)'ne göre, yakınsama geçerliliğinin sağlanması için tüm faktör yüklerinin 0,50 'den yüksek olması, ideal olarak ise 0,70 ve üzerinde yer alması gerekmektedir. Tablo 5 incelendiğinde boyutlara ait faktör yüklerinin 0,621 ile 0,938 arasında değiştiği gözlenmektedir. Niyet değişkeninde yer alan iki faktör $(0,621 ; 0,652)$ dışında bütün faktörler ideal değerin üzerinde yer almaktadır. Bunun yanı sıra bütün faktörlerin 0,50 kritik değerinin üzerinde olduğunu söylemek mümkündür. Yakınsama geçerliliğinin sağlanması için diğer önemli husus AVE ve CR değerleridir. Hair vd. (2014: 619)'ne göre AVE değerlerinin 0,50 'nin üzerinde, $C R$ değerlerinin ise 0,70 'in üzerinde olması gerekmektedir. Tablo 5 incelendiğinde, değişkenlere ilişkin AVE değerlerinin 0,556 ile 0,863 arasında değiştiği; CR değerlerinin ise 0,850 ile 0,950 aralığında olduğu gözlenmektedir. Bu bulgular araştırma ölçeklerinin yakınsama geçerliliği için önemli birer kanıttır.

Tablo 5. Değişkenlere Iliş̧kin Güvenilirlik ve Geçerlilik Bulguları

\begin{tabular}{|c|c|c|c|c|}
\hline Faktör & Faktör Yükü & AVE & CR & Cronbach $\alpha$ \\
\hline \multirow{5}{*}{ Tutum } & 0,812 & \multirow{5}{*}{0,625} & \multirow{5}{*}{0,893} & \multirow{5}{*}{0,908} \\
\hline & 0,809 & & & \\
\hline & 0,791 & & & \\
\hline & 0,780 & & & \\
\hline & 0,759 & & & \\
\hline \multirow{5}{*}{ Niyet } & 0,857 & \multirow{5}{*}{0,556} & \multirow{5}{*}{0,861} & \multirow{5}{*}{0,944} \\
\hline & 0,834 & & & \\
\hline & 0,736 & & & \\
\hline & 0,652 & & & \\
\hline & 0,621 & & & \\
\hline
\end{tabular}


Tablo 5. Değişkenlere İlişkin Güvenilirlik ve Geçerlilik Bulguları (Devam)

\begin{tabular}{|c|c|c|c|c|}
\hline Faktör & Faktör Yükü & AVE & CR & Cronbach $\alpha$ \\
\hline \multirow{5}{*}{ Algılanan Risk } & 0,804 & \multirow{5}{*}{0,598} & \multirow{5}{*}{0,881} & \multirow{5}{*}{0,848} \\
\hline & 0,799 & & & \\
\hline & 0,780 & & & \\
\hline & 0,774 & & & \\
\hline & 0,704 & & & \\
\hline \multirow{3}{*}{$\begin{array}{l}\text { Algılanan Kullanım } \\
\text { Kolaylığı }\end{array}$} & 0,861 & \multirow{3}{*}{0,717} & \multirow{3}{*}{0,883} & \multirow{3}{*}{0,909} \\
\hline & 0,854 & & & \\
\hline & 0,824 & & & \\
\hline \multirow{3}{*}{ Algılanan Fayda } & 0,862 & \multirow{3}{*}{0,655} & \multirow{3}{*}{0,850} & \multirow{3}{*}{0,894} \\
\hline & 0,826 & & & \\
\hline & 0,734 & & & \\
\hline \multirow{3}{*}{ Subjektif Norm } & 0,938 & \multirow{3}{*}{0,863} & \multirow{3}{*}{0,950} & \multirow{3}{*}{0,916} \\
\hline & 0,934 & & & \\
\hline & 0,914 & & & \\
\hline
\end{tabular}

Ayrışma geçerliliğinin sağlandığını söyleyebilmek için her değişkene ait AVE değerlerinin karekökünün, değişkenler arasındaki korelasyonlardan büyük olması istenir (Fornell ve Larcker, 1981). Tablo 6 'da görüldüğü üzere bütün değişkenler arasındaki korelasyon değerleri, ilgili değişkenlerin AVE değerlerinin karekökünden küçüktür.

Tablo 6. AVE Değerlerinin Karekökü ve Korelasyon Katsayıları

\begin{tabular}{|c|c|c|c|c|c|c|}
\hline & $\mathbf{1}$ & $\mathbf{2}$ & $\mathbf{3}$ & $\mathbf{4}$ & $\mathbf{5}$ & $\mathbf{6}$ \\
\hline $\mathbf{T}$ & $\mathbf{0 , 7 9 0}$ & & & & & \\
\hline $\mathbf{N}$ & $0,657^{*}$ & $\mathbf{0 , 7 4 6}$ & & & & \\
\hline AKK & $0,398^{*}$ & $0,515^{*}$ & $\mathbf{0 , 8 4 6}$ & & & \\
\hline AFA & $0,457^{*}$ & $0,537^{*}$ & $0,537^{*}$ & $\mathbf{0 , 8 0 9}$ & & \\
\hline AR & $-0,254^{*}$ & $-0,298^{*}$ & $0,256^{*}$ & $0,264^{*}$ & $\mathbf{0 , 6 9 6}$ & \\
\hline $\mathbf{S N}$ & $0,250^{*}$ & $0,256^{*}$ & $0,143^{*}$ & $0,164^{*}$ & 0,102 & $\mathbf{0 , 9 2 9}$ \\
\hline
\end{tabular}

T: Tutum; N: Niyet; AKK: Algılanan Kullanım Kolaylığı; AFA: Algılanan Fayda; AR: Algılanan Risk;

SN: Subjektif Norm

* Korelasyonlar 0,01 düzeyinde anlamlıdır.

** Köşegende yer alan koyu değerler ilgili boyutun AVE değerinin karekökünü ifade etmektedir.

Elde edilen bulgular araştırma kapsamında kullanılan ölçeklerin geçerliliği ve güvenilirliği için önemli birer kanıttır. Bulgular bir bütün olarak değerlendirildiğinde araştırma verisinin güvenilir olduğunu ve kullanılan ölçeklerin yapı geçerliliğinin sağlandığını söylemek mümkündür.

\subsection{Araştırma Modelinin Yapısal Eşitlik Modeli ile Test Edilmesi}

Bu bölümde, araştırmanın teorik modelinde beklenen etkilerin sınanması ve modelin bir bütün olarak anlamlı olup olmadığının belirlenmesi amacıyla yapılan Yapısal Eşitlik Modeli analizi bulguları sunulmuştur. Yapısal eşitlik modeli analizindeki asıl amaç gözlenen ya da gözlenemeyen değişkenlerin arasındaki ilişkilerin sınanmasıdır (Reisinger ve Turner, 1999). Bu araştırmada yapısal eşitlik modeli analizi AMOS 24 paket programı ile yapılmışır. Şekil 3 'de araştırmanın teorik modelinin yapısal eşitlik modellemesi ile testinin ardından ortaya çıkan etkileşim değerleri yer almaktadır. 
Şekil 3. Teorik Modelin Yapısal Eşitlik Modeli Etkileşim Değerleri

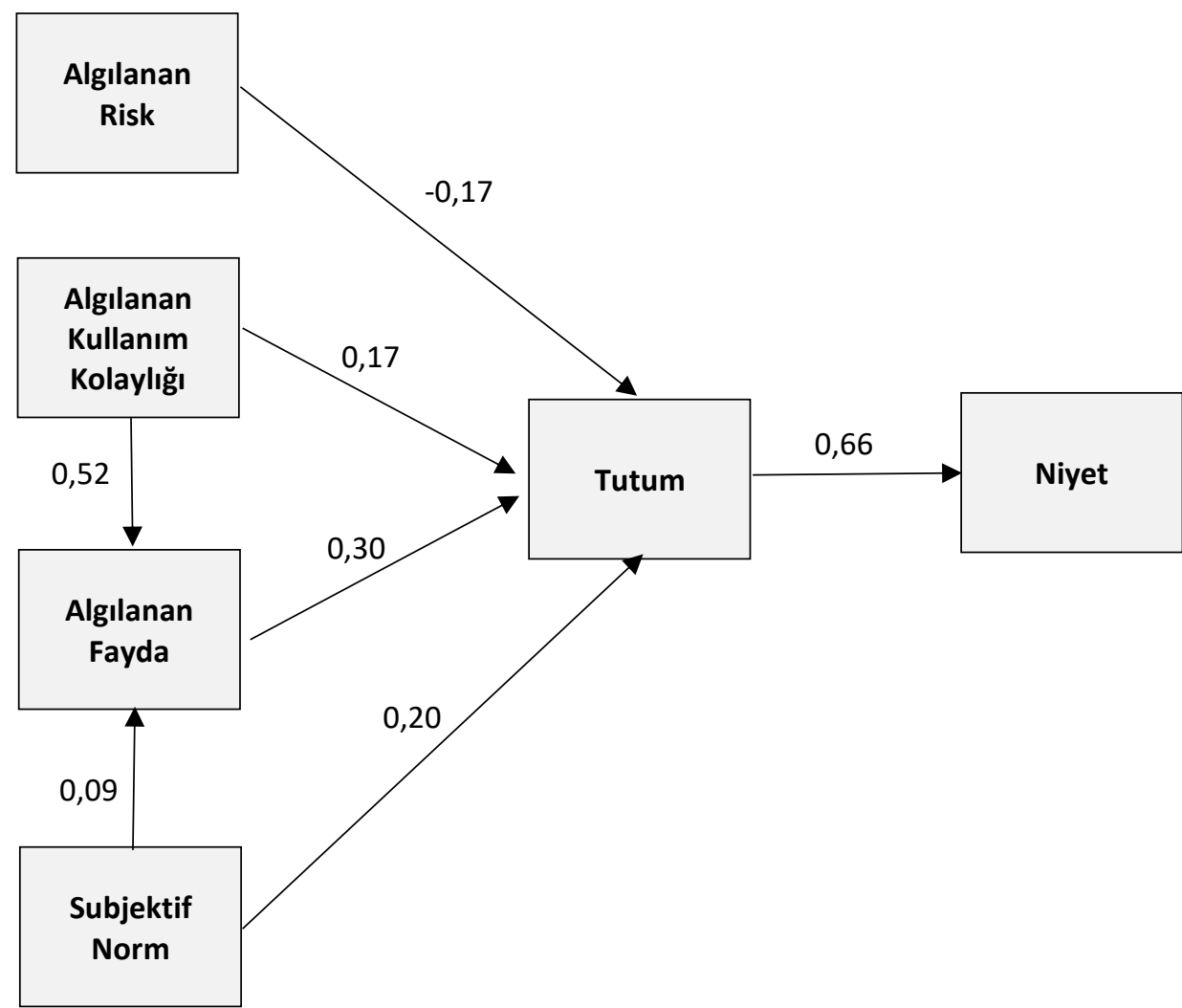

Tablo 7'de araştırmanın teorik modelinin yapısal eşitlik modeli ile test edilmesinin ardından ortaya çıkan uyum iyiliği endeks değerlerinden bazıları sunulmuştur. Elde edilen bulgular incelendiğinde, $\chi^{2} / s d$, SRMR, AGFI, RMSEA ve CFI değerlerinin iyi uyum aralığında olduğu gözlenmektedir. Bulgular değerlendirildiğinde, modelin yapısal olarak geçerli olduğu söylenebilir.

Tablo 7. Yapısal Eşitlik Modeli Uyum İyiliği Değerleri

\begin{tabular}{|c|c|c|c|}
\hline UYUM ÖLÇÜLERi & iYi UYUM & $\begin{array}{c}\text { KABUL EDiLEBiLiR } \\
\text { UYUM }\end{array}$ & $\begin{array}{c}\text { GÖZLENEN } \\
\text { DEĞER }\end{array}$ \\
\hline$\chi^{2} /$ SD & $0 \leq \chi^{2} / s d \leq 2$ & $2<\chi^{2} / s d \leq 3$ & 1,597 \\
\hline SRMR & $0 \leq S$ RMR $\leq 0,05$ & $0,05 \leq$ SRMR $\leq 0,10$ & 0,0274 \\
\hline AGFI & $0,90 \leq$ AGFI $\leq 1,00$ & $0,85 \leq$ AGFI $\leq 0,90$ & 0,958 \\
\hline CFI & $0,97 \leq C F I \leq 1,00$ & $0,95 \leq C F I \leq 0,97$ & 0,994 \\
\hline RMSEA & $0 \leq$ RMSEA $\leq 0,05$ & $0,05 \leq$ RMSEA $\leq 0,08$ & 0,047 \\
\hline
\end{tabular}

Kaynak: Bayram, N. (2010). Yapısal eşitlik modellemesine giriş: AMOS uygulamaları (1. Baskı). Bursa: Ezgi Kitabevi.

Tablo 8'de araştırma hipotezlerinin yapısal eşitlik modeli ile test sonuçları görülmektedir. Bulgular incelendiğinde, algılanan kullanım kolaylığı $(\beta=0,171, p=0,007)$, algılanan fayda $(\beta=0,297, p=0,001)$, algılanan risk $(\beta=-0,173, p=0,001)$ ve subjektif norm $(\beta=0,198, p=0,001)$ değişkenlerinin tutum üzerindeki etkisinin istatistiksel olarak anlamlı olduğu söylenebilir. Bu sonuçlar algılanan kullanım kolaylığı, algılanan fayda ve subjektif norm değişkenlerinin tutum üzerinde pozitif yönlü; algılanan risk değişkeninin ise negatif yönlü bir etkiye sahip olduğunu göstermektedir. Dolayısıyla $\mathrm{H}_{1}, \mathrm{H}_{2}, \mathrm{H}_{3}$ ve $\mathrm{H}_{4}$ hipotezleri desteklenmiştir. 
Tablo 8. Araştırma Hipotezlerinin Test Edilmesi

\begin{tabular}{|c|c|c|c|c|c|c|c|c|}
\hline Hipotez & $\begin{array}{l}\text { Bağımsız } \\
\text { Değişken }\end{array}$ & $\begin{array}{l}\text { Bağımlı } \\
\text { Değişken }\end{array}$ & $\mathbf{R}^{2}$ & $\begin{array}{c}\text { Standardize } \\
\beta\end{array}$ & $\begin{array}{l}\text { Standart } \\
\text { Hata }\end{array}$ & $\mathbf{t}$ & $\mathbf{p}$ & Sonuçlar \\
\hline $\mathrm{H}_{1}$ & $\begin{array}{l}\text { Alglanan } \\
\text { Kullanım } \\
\text { Kolayllğı }\end{array}$ & Tutum & \multirow{4}{*}{0,29} & 0,171 & 0,075 & 2,720 & 0,007 & Desteklendi \\
\hline $\mathrm{H}_{2}$ & $\begin{array}{l}\text { Alglanan } \\
\text { Fayda }\end{array}$ & Tutum & & 0,297 & 0,054 & 4,816 & 0,001 & Desteklendi \\
\hline $\mathrm{H}_{3}$ & $\begin{array}{l}\text { Alglanan } \\
\text { Risk }\end{array}$ & Tutum & & $-0,173$ & 0,038 & $-3,204$ & 0,001 & Desteklendi \\
\hline $\mathrm{H}_{4}$ & $\begin{array}{l}\text { Subjektif } \\
\text { Norm }\end{array}$ & Tutum & & 0,198 & 0,031 & 3,729 & 0,001 & Desteklendi \\
\hline $\mathrm{H}_{5}$ & $\begin{array}{l}\text { Subjektif } \\
\text { Norm }\end{array}$ & $\begin{array}{l}\text { Alglanan } \\
\text { Fayda }\end{array}$ & \multirow[b]{2}{*}{0,30} & 0,089 & 0,035 & 1,706 & 0,088 & Desteklenmedi \\
\hline $\mathrm{H}_{6}$ & $\begin{array}{l}\text { Alglanan } \\
\text { Kullanım } \\
\text { Kolaylığı }\end{array}$ & $\begin{array}{l}\text { Alglanan } \\
\text { Fayda }\end{array}$ & & 0,524 & 0,072 & 10,087 & 0,001 & Desteklendi \\
\hline $\mathrm{H}_{7}$ & Tutum & Niyet & 0,43 & 0,655 & 0,046 & 14,141 & 0,001 & Desteklendi \\
\hline
\end{tabular}

Hipotezlerin test sonuçları, algılanan kullanım kolaylığı $(\beta=0,524, p=0,001)$ değişkeninin algılanan fayda üzerinde istatistiksel olarak anlamlı bir etkisinin olduğunu göstermektedir. Öte yandan, subjektif norm $(\beta=0,089, p=0,088)$ değişkeninin algılanan fayda değişkeni üzerinde istatistiksel olarak anlamlı bir etkisi bulunamamıştır. Dolayısıyla $\mathrm{H}_{5}$ hipotezi desteklenemezken, $\mathrm{H}_{6}$ hipotezi desteklenmiştir. Tutum değişkeninin satın alma niyeti üzerinde beklenen etkisi ise $(\beta=0,655, p=0,001)$ bu çalışma özelinde tespit edilmiştir. $B u$ doğrultuda $\mathrm{H}_{7}$ hipotezi desteklenmiştir.

\section{Sonuç ve Öneriler}

Bu araştırmada tüketicilerin kombi tercihlerinde etkili olan faktörler TKM kapsamında incelenmiştir. Bu amaç doğrultusunda, öncelikle bir literatür araştırması yapılmış ve araştırma modeline doğalgaz kombi cihazını satın almaya yönelik tutum üzerinde etkili olacağı değerlendirilen subjektif norm ve algılanan risk değişkenleri eklenmiştir. Kurgulanan araştırma modelinin test edilmesi sonucunda, literatür için faydalı olacağı düşünülen çeşitli bulgular ortaya çıkmıştır. Çalışmanın bu bölümünde araştırmanın sonuçlarına, araştırmacılar ve sektör temsilcileri için çeşitli önerilere ve çalışmanın sınırlılıklarına yer verilmiştir.

Araştırma kapsamında, katııımcıların kullanım kolaylığı algılamalarının satın almaya yönelik tutumları üzerindeki etkisi beklendiği gibi pozitif ve istatistiki olarak anlamlı bulunmuştur. Araştırmanın bu bulgusu literatürde yer alan bazı sonuçlarla örtüşmektedir (Shih, 2004; Yaghoubi vd., 2010; Chin ve Lin, 2015; Tsaur ve Lin, 2018; Li ve Wang, 2019; Hua ve Wang, 2019; Ali vd., 2020). Bu sonuç, tüketicilerin kombi cihazı kullanımını kolay olarak algılamalarının satın almaya yönelik tutumlarını olumlu bir biçimde etkilediğini göstermektedir. Buradan hareketle, bu araştırma özelinde doğalgaz kombi cihazı satın almaya veya kullanmaya yönelik olumlu tutum gelişmesinde, kombinin kullanımının kolay olmasının önemli bir faktör olduğunu söylemek mümkündür.

Araştırma sonucunda, algılanan fayda değişkeninin tutum üzerinde pozitif ve istatistiki olarak anlamlı bir etkisi olduğu sonucuna ulaşılmıştır. Bu sonuç, doğalgaz kombi cihazı satın alan tüketicilerin ürünü faydalı olarak algılamalarının, satın almaya yönelik tutum geliştirmelerinde etkili olduğunu göstermektedir. Araştırmanın bu sonucu, Shih (2004) ve Kardooni vd. (2016)'nin bulgularılyla paralellik göstermektedir. Bu bulguya göre, tüketicilerin doğalgaz kombi cihazını faydalı görmeleri halinde, bu cihazı satın almaya yönelik tutumlarının olumlu yönde gelişeceği ifade edilebilir. 
Araştırma bulguları, tüketicilerin doğalgaz kombi cihazından algıladığı riskin, bu ürünü satın almaya yönelik tutumlarına etkisinin beklendiği gibi negatif ve anlamlı olduğunu göstermektedir. Dolayısıyla, tüketicilerin doğalgaz kombi cihazından artan risk algılarının, bu ürünü satın almaya yönelik tutumlarını olumsuz bir biçimde etkileyeceğini söylemek mümkündür. Bu sonuç, Han vd. (2019)'nin çalışma bulgularıyla örtüşmektedir.

Subjektif norm değişkeninin tutum değişkeni üzerinde pozitif ve istatistiki olarak anlamlı bir etkisinin olduğu sonucu, tüketicilerin doğalgaz kombi cihazı satın alırken referans gruplarının onaylarına önem verdiklerini göstermektedir. Araştırmanın bu sonucu daha önce yapılan bazı çalışmalarla benzerlik göstermektedir (Yang vd., 2012; Erciş ve Aydın, 2015; Köylüoğlu vd., 2018). Subjektif norm değişkeninin algılanan fayda değişkeni üzerinde anlamlı bir etkisi saptanamamıştır. Bu sonuç, Paramaeswari ve Sarno (2020)'nun çalışmasındaki bulgularla benzerlik göstermektedir. Bu çalışma özelinde bireylerin doğalgaz kombi cihazı tercihlerinde referans gruplarının verdiği bilgi ve tavsiyelerin, onların ürünü daha faydalı görmesine sebebiyet vermediğini söylemek mümkündür. Bu doğrultuda, subjektif norm değişkeninin aritmetik ortalamasından anlaşıldığı üzere tüketicilerin referans gruplarının tavsiyelerine kulak verdikleri, ancak bu tavsiyelerin ürünü faydalı olarak algılamalarına neden olacak doğrultuda etkili olmadığı söylenebilir.

Araştırma sonucunda, algılanan kullanım kolaylığı değişkeninin algılanan fayda üzerinde oldukça yüksek bir etkisi olduğu görülmüştür. Bu durum, tüketicilerin doğalgaz kombi cihazlarını fazla çaba sarf etmeden kullanacaklarına inandıklarında, cihazı kullanmanın onlar için faydalı olacağına da inandıklarını göstermektedir. Venkatesh (2000)'e göre tüm şartların sağlandığı durumlarda algılanan fayda, algılanan kullanım kolaylığından etkilenecektir. Çünkü bireyin bir sistemin kullanımını kolay olarak algılaması, o sistemden daha kolay olarak fayda sağlayabileceğini (sistemin kullanışlı olacağını) düşünmesine neden olacaktır.

Araştırmanın son hipotezi olan tüketicilerin tutumlarının, satın almaya yönelik niyetlerini pozitif bir biçimde etkilediği yönündeki hipotez desteklenmiştir. Bu durum, tüketicilerin doğalgaz kombi cihazlarına yönelik olumlu bir tutum geliştirmelerinin, onların satın alma niyetini pozitif yönde etkilediğini göstermektedir. Araştırmanın bu bulgusu literatürde yer alan benzer bazı araştırmaların sonuçlarıyla örtüşmektedir (Maichum vd., 2016; Suki, 2016; Yadav ve Pathak, 2016; Tan vd., 2017; Kartawinata vd., 2020; Ali, Shafiq ve Andejany, 2021).

TKM kapsamında yürütülen çalışmalarda algılanan kullanım kolaylığı, algılanan fayda, tutum ve niyet değişkenleri arasında pozitif ve anlamlı bir ilişki beklenmektedir (Szajna, 1996; Wang, Lo ve Fang, 2008; Ha ve Stoel, 2009; Pinho ve Soares, 2011; Chin ve Lin, 2015; Park, Hwang, Ko ve Kim, 2017; Ali vd., 2020). Bu çalışma özelinde de beklenen söz konusu ilişkiler doğrulanmıştır. Ayrıca algılanan risk değişkeninin tutum üzerinde beklenen negatif etkisi, literatürle uyumlu bir biçimde (Chen vd., 2012; Wu ve Chen, 2014; Han vd., 2019) doğrulanmıştır. Bunlara ek olarak subjektif norm değişkeninin tutum üzerinde beklenen etkisi (Yang vd., 2012; Erciş ve Aydın, 2015) doğrulanırken, algılanan fayda üzerindeki etkisi doğrulanamamıştır.

Araştırma sonucunda, doğalgaz kombi cihazı kullanan tüketicilerin, cihazın kullanımının kolay ve faydalı olduğunu düşünmesi halinde satın almaya yönelik tutum geliştirebileceği ortaya konmuştur. Sektörde yer alan firmalara, pazarlama iletişimi mesajlarında bu unsurlara vurgu yapmalarının önemli olduğu önerisinde bulunulabilir. Benzer bir şekilde tüketicilerin doğalgaz kombi cihazının kullanımını kolay algılamaları halinde, cihazın daha faydalı olduğunu düşündükleri sonucuna ulaşılmıştır. Buradan hareketle, pazarlama faaliyetleri sürdürülürken cihazın kullanımı hakkında detaylı bilgilendirme yaparak, tüketicilerin aklındaki kullanıma yönelik sorulara pratik yanıtlar verilmesinin ürünün daha faydalı olarak algılanmasına yardımcı olacağı ve ürüne yönelik olumlu tutum gelişmesine katkı sağlayacağı söylenebilir. Araştırmada ortaya çıkan doğalgaz kombi cihazında risk algısı oluşmasının satın almaya yönelik tutumu olumsuz bir şekilde etkilediği sonucundan hareketle, sektörde yer alan firmalara tüketicilerin risk algısını azaltmak için, tüketici araştırmalarına önem vermeleri ve onların hangi konularda risk algıladığını tespit etmeleri gerektiği söylenebilir. Bu çalışmada algılanan riskin hangi unsurların etkisiyle ortaya çıktığı konusu incelenmemiştir. Bu doğrultuda, tüketicilerin doğalgaz kombi cihazında risk algılama nedenleri başka araştırmalarla incelenmelidir. Bu riskin nedeninin finansal mı, yoksa performans verimiyle mi alakalı olduğu, tüketicilerin bu 
üründe güvenlikten kaynaklı bir risk algılayıp algılamadıkları gibi sorulara cevap aranması faydalı olacaktır. Tüketicilerin hangi risk türlerini daha yoğun algıladıkları tespit edilerek, bunları azaltmaya yönelik çabalara girişilmelidir.

Araştırmada yargısal örnekleme yöntemi kullanılmıştır. Yargısal örnekleme, tesadüfi olmayan örnekleme türlerinden biri olduğu için araştırma sonuçlarının genellenmesi doğru olmayacaktır. Bu konuda daha sonra yapılacak araştırmalarda, tesadüfi örnekleme yöntemlerinden birinin kullanılması durumunda, sonuçların geçerliliği artırılabilecektir.

Araştırmanın saha çalışması pandemi sürecinde yürütüldüğü için yüz yüze gerçekleşmesi planlanan anket toplama süreci çevrimiçi ortamda yapılmıştır. Bu durum araştırmanın önemli bir kısıtıdır. Her ne kadar çevrimiçi anketler gün geçtikçe artsa da bu konu özelinde verinin yüz yüze bir ortamda toplanmasının veri kalitesi bakımından daha iyi olacağı düşünülmektedir.

\section{Beyan ve Açıklamalar (Declarations and Disclosures)}

Yazarların Etik Sorumlulukları (Ethical Responsibilities of Authors): Bu çalışmanın yazarları, araştırma ve yayın etiği ilkelerine uyduklarını kabul etmektedirler.

Etik Kurul Onayı (Ethical Approval): Çalışmada kullanılan ölçeğin ve toplanan verilerin etik açıdan uygunluğu Balıkesir Üniversitesi Sosyal ve Beşeri Bilimler Etik Komisyonunun 23.09.2021 tarih ve 2021/04 sayılı toplantısında onaylanmıştır.

Çıkar Çatışması (Conflicts of Interest): Yazarlar tarafından herhangi bir çıkar çatışması beyan edilmemiştir.

Finansal Destek (Funding): Yazarlar, çalışmanın hazırlanması ve/veya yayınlanması sürecinde herhangi bir finansal destek almamışlardır.

Yazar Katkı Oranı (Author Contributions): Yazarlar, çalışmaya olan katkılarını şu şekilde beyan etmişlerdir: Kavramlaştırma ve çalışma dizaynı, V. Özbek; verilerin toplanması, i. Tahtacı; verilerin analizi ve sonuçların yorumlanması, V. Özbek ve I. Tahtacı; çalışmanın ilk/taslak halinin yazııması, i. Tahtacı ve V. Özbek; çalışmanın gözden geçirilmesi ve düzenlenmesi/düzeltilmesi, V. Özbek. Çalışmanın ilk ve son hali tüm yazarlar tarafından okunmuş ve onaylanmış olup, yazarlar çalışmalarıyla ilgili sorumluluğu kabul etmektedirler.

intihal Denetimi (Plagiarism Checking): Bu çalışma, intihal tarama programı kullanılarak intihal taramasından geçirilmiştir.

\section{Kaynaklar}

Ajzen, l., \& Driver, B. L. (1991). Prediction of leisure participation from behavioral, normative, and control beliefs: An application of the theory of planned behavior. Leisure Sciences, 13(3), 185-204.

Ali, S., Poulova, P., Akbar, A., Javed, H. M. U., \& Danish, M. (2020). Determining the influencing factors in the adoption of Solar photovoltaic technology in Pakistan: A decomposed technology acceptance model approach. Economies, 8(4), 1-20.

Ali, M. R., Shafiq, M., \& Andejany, M. (2021). Determinants of consumers' intentions towards the purchase of energy efficient appliances in Pakistan: An extended model of the theory of planned behavior. Sustainability, 13(2), 117.

Bayram, N. (2010). Yapısal eşitlik modellemesine giriş: AMOS uygulamaları (1. Baskı). Bursa: Ezgi Kitabevi.

Bilgin Erte, F. (2020). Algılanan faydanın müşteri sadakati yaratmadaki önemi ve sadakat programları üzerine bir araştırma. İstanbul: Galatasaray Üniversitesi Sosyal Bilimler Enstitüsü, Yayınlanmamış Yüksek Lisans Tezi, Istanbul.

Ceylan, H. H., Genç, E., \& Erem, I. (2013). Tüketicilerin internet bankacilığını benimsemesini etkileyen faktörlerin yapısal eşitlik modeli ile araştırılması. Anadolu University Journal of Social Sciences, 13(3), 143-154.

Chen, H. S., Chen, C. Y., Chen, H. K., \& Hsieh, T. (2012). A study of relationships among green consumption attitude, perceived risk, perceived value toward hydrogen-electric motorcycle purchase intention. Aasri Procedia, 2, 163168. 
Chin, J., \& Lin, S. C. (2015). Investigating users' perspectives in building energy management system with an extension of technology acceptance model: A case study in indonesian manufacturing companies. Procedia Computer Science, 72, 31-39.

Çelik, H., \& İpçioğlu, İ. (2006). Gönüllü teknoloji kabulü: İnternet kullanımını benimseme davranışı üzerine bir araştırma. Hacettepe Üniversitesi Iktisadi ve Idari Bilimler Fakültesi Dergisi, 24(1), 111-159.

Çivici, T., \& Kale, S. (2007). Mimari tasarım bürolarında bilişim teknolojilerinin kullanımını etkileyen faktörler: Bir yapısal denklem modeli. Inşaat yönetimi kongresi bildiriler kitabı (ss.119-128).

Davis, F. D. (1986). A technology acceptance model for empirically testing new end-user information systems: Theory and results. Sloan School of Management, Massachusetts Institute of Technology, Doctoral Dissertation.

Davis, F. D. (1989). Perceived usefulness, perceived ease of use, and user acceptance of information technology. MIS Quarterly, 13(3), 319-340.

Davis, F. D., Bagozzi, R. P., \& Warshaw, P. R. (1989). User acceptance of computer technology: A comparison of two theorical models. Management Science, 35(8), 982-1003.

Davis, F. D., \& Venkatesh, V. (1996). A critical assessment of potential measurement biases in the technology acceptance model: Three experiments. International Journal of Human-Computer Studies, 45(1), 19-45.

Durmaz, Y. (2011). Tüketici davranışı. Ankara: Detay Yayıncılık.

Etikan, I., Musa, S. A., \& Alkassim, R. S. (2016). Comparison of convenience sampling and purposive sampling. American Journal of Theoretical and Applied Statistics, 5(1), 1-4.

Enerji Piyasası Düzenleme Kurumu, (2020). https://www.epdk.gov.tr/Detay/Icerik/3-0-166/resmi-istatistikleri (Erişim Tarihi: 27.09.2021).

Engin, N. (2010) Enerji kaynağı olarak doğalgaz ve Türkiye. Marmara Coğrafya Dergisi, (22), 233-244.

Erciş, A., \& Aydın, H. (2015). Mobil viral iletişimde tutum, niyet ve davranışları etkileyen faktörlerin ölçülmesi. Ataturk University Journal of Economics \& Administrative Sciences, 29(1), 205-218.

Erdoğdu, E. (2010). Natural gas demand in Turkey. Applied Energy, 87(1), 211-219.

Ertuğrul, ì., \& Aytaç, E. (2012). Analitik ağ süreci yöntemi ve kombi seçim probleminde uygulanabilirliği. Dokuz Eylül Üniversitesi Iktisadi ve Idari Bilimler Fakültesi Dergisi, 27(2), 79-92.

Featherman, M. S., \& Pavlou, P. A. (2003). Predicting e-services adoption: A perceived risk facets perspective. International Journal of Human-Computer Studies, 59(4), 451-474.

Fornell, C., \& Larcker, D. F. (1981). Evaluating structural equation models with unobservable variables and measurement error. Journal of Marketing Research, 18(1), 39-50.

Hair, J. F., Black, W. C., Babin, B. J., \& Anderson, R. E. (2014). Multivariate data analysis (Seventh Edition). Pearson New International Edition.

Ha, S., \& Stoel, L. (2009). Consumer e-shopping acceptance: Antecedents in a technology acceptance model. Journal of Business Research, 62(5), 565-571.

Han, H., Yu, J., \& Kim, W. (2019). An electric airplane: Assessing the effect of travelers' perceived risk, attitude, and new product knowledge. Journal of Air Transport Management, 78, 33-42.

Hua, L., \&Wang, S. (2019). Antecedents of consumers' intention to purchase energy-efficient appliances: An empirical study based on the technology acceptance model and theory of planned behavior. Sustainability, 11(10), 1-17.

Joo, J., \& Sang, Y. (2013). Exploring koreans' smartphone usage: An integrated model of the technology acceptance model and uses and gratifications theory. Computers in Human Behavior, 29, 2512-2518.

Kardooni, R., Yusoff, S. B., \& Kari, F. B. (2016). Renewable energy technology acceptance in Peninsular Malaysia. Energy Policy, 88, 1-10.

Karimzadeh, S., \&Salehi, S. (2021). A study of households' intention towards solar panel installation case study: Villagers of the northern regions of Iran. Environmental Sociology, 7(2), 1-13.

Kartawinata, B. R., Maharani, D., Pradana, M., \& Amani, H. M. (2020). The role of customer attitude in mediating the effect of green marketing mix on green product purchase intention in love beauty and planet products in Indonesia. In Proceedings of the International Conference on Industrial Engineering and Operations Management, 1 (pp. 3023-3033).

Koç, E. (2019). Tüketici davranışı ve pazarlama stratejileri: Global ve yerel yaklaşım (8. Baskı). Ankara: Seçkin Yayıncılık.

Köylüoğlu, A. S., Acar, Ö. E., \& İnan, Ü. S. E. (2018). Çevre dostu otomobil satın alma davranışlarının belirlenmesi üzerine bir araştırma. İşletme Araştırmaları Dergisi, 10(2), 403-422. 
Lee, M. C. (2009). Factors influencing the adoption of internet banking: An integration of TAM and TPB with perceived risk and perceived benefit. Electronic Commerce Research and Applications, 8(3), 130-141.

Lee, Y., Kozar, K. A., \& Larsen, K. R. (2003). The technology acceptance model: Past, present, and future. Communications of the Association for information systems, 12(1), 752-780.

Lee, C., \& Wan, G. (2010). Including subjective norm and technology trust in the technology acceptance model: A case of e-ticketing in China. Acm Sigmis Database: The Database for Advances in Information Systems, 41(4), 40-51.

Li, H., \& Wang, S. (2019). Antecedents of consumers' intention to purchase energy-efficient appliances: An empirical study based on the technology acceptance model and theory of planned behavior. Sustainability, 11(10), 1-17.

Maichum, K., Parichatnon, S., \& Peng, K. C. (2016). Application of the extended theory of planned behavior model to investigate purchase intention of green products among Thai consumers. Sustainability, 8(10), 1-20.

Mitchell, V. W. (1992). Understanding consumers' behaviour: Can perceived risk theory help. Management Decision, 30(3), 26-31.

Moslehpour, M., Pham, V. K., Wong, W. K., \& Bilgiçli, i. (2018). E-purchase intention of Taiwanese consumers: Sustainable mediation of perceived usefulness and perceived ease of use. Sustainability, 10(1), 1-17.

Moutinho, L. (1987). Consumer behavior in tourism. Journal of Marketing, 21(10), 1-44.

Murphy, P. E., \& Enis, B. M. (1986). Classifying products strategically. Journal of Marketing, 50(3), 24-42.

Nakip, M. (2006). Pazarlama araştırmaları teknikler ve SPSS destekli uygulamalar. Ankara: Seçkin Yayıncılık.

Öztürk, A., \& Temizkan, V. (2018). Tüketicilerin anneler gününde hediye satın alma davranışlarının sebepli davranış teorisi bağlamında incelenmesi. EKEV Akademi Dergisi, 22(76), 37-56.

Quintal, V. A., Lee, J. A., \& Soutar, G. N. (2010). Risk, uncertainty and the theory of planned behavior: A tourism example. Tourism Management, 31(6), 797-805.

Paramaeswari, R. P. I., \& Sarno, R. (2020). Analysis of e-commerce (Bukalapak, Shopee, and Tokopedia) acceptance models using TAM2 method. In 2020 International Seminar on Application for Technology of Information and Communication (iSemantic), 505-510.

Park, E. S., Hwang, B., Ko, K., \& Kim, D. (2017). Consumer acceptance analysis of the home energy management system. Sustainability, 9(12), 1-15.

Pavlou, P. A., \& Fygenson, M. (2006). Understanding and predicting electronic commerce adoption: An extension of the theory of planned behavior. MIS Quarterly, 30(1), 115-143.

Perla, R. J., \& Provost, L. P. (2012). Judgment sampling: A health care improvement perspective. Quality Management in Healthcare, 21(3), 169-175.

Peter, J. P., \& Ryan, M. J. (1976). An investigation of perceived risk at the brand level. Journal of Marketing Research, 13(2), 184-188.

Pinho, J. C. M. R., \& Soares, A. M. (2011). Examining the technology acceptance model in the adoption of social networks. Journal of Research in Interactive Marketing, 5(2-3), 116-129.

Reisinger, Y., \& Turner, L. (1999). Structural equation modeling with lisrel: Application in tourism. Tourism Management, 20(1), 71-88.

Sarak, H., \& Satman, A. (2003). The degree-day method to estimate the residential heating natural gas consumption in Turkey: A case study. Energy, 28(9), 929-939.

Schepers, J., \& Wetzels, M. (2007). A meta-analysis of the technology acceptance model: Investigating subjective norm and moderation effects. Information \&Management, 44(1), 90-103.

Shih, H. P. (2004). An empirical study on predicting user acceptance of e-shopping on the web. Information and Management, 41(3), 351-368.

Sparks, P., Guthrie, C. A., \& Shepherd, R. (1997). The dimensional structure of the perceived behavioral control construct 1. Journal of Applied Social Psychology, 27(5), 418-438.

Suki, N. M. (2016). Green product purchase intention: impact of green brands, attitude, and knowledge. British Food Journal, 118(12), 2893-2910.

Surendran, P. (2012). Technology acceptance model: A survey of literature. International Journal of Business and Social Research, 2(4), 175-178.

Szajna, B. (1996). Empirical evaluation of the revised technology acceptance model. Management Science, 42(1), 85-92. 
Tan, C. S., Ooi, H. Y., \& Goh, Y. N. (2017). A moral extension of the theory of planned behavior to predict consumers' purchase intention for energy-efficient household appliances in Malaysia. Energy Policy, 107, 459-471.

Taylor, S., \& Todd, P. (1995). Decomposition and crossover effects in the theory of planned behavior: A study of consumer adoption intentions. International Journal of Research in Marketing, 12(2), 137-155.

Tsaur, R. C., \& Lin, Y. H. (2018). Exploring the consumer attitude of building-attached photovoltaic equipment using revised technology acceptance model. Sustainability, 10(11), 4177.

Venkatesh, V. (2000). Determinants of perceived ease of use: Integrating control, intrinsic motivation, and emotion into the technology acceptance model. Information Systems Research, 11(4), 342-365.

Venkatesh, V., \& Davis, F. D. (1996). A model of the antecedents of perceived ease of use: Development and test. Decision Sciences, 27(3), 451-481.

Wang, C. C., Lo, S. K., \& Fang, W. (2008). Extending the technology acceptance model to mobile telecommunication innovation: The existence of network externalities. Journal of Consumer Behaviour: An International Research Review, 7(2), 101-110.

Wu, S. I., \& Chen, J. Y. (2014). A model of green consumption behavior constructed by the theory of planned behavior. International Journal of Marketing Studies, 6(5), 119.

Wu, J. H., \& Wang, S. C. (2005). What drives mobile commerce? An empirical evaluation of the revised technology acceptance model. Information and Management, 42, 719-729.

Yaghoubi, N. M., Motlaq, S. V., Moghadam, I. H., \& Motlaq, T. V. (2010). Factors influencing the adoption of electronic commerce in Iranian SMEs: An integration of TAM2 and TPB with cost saving. Journal of US-China Public Administration, 7(12), 91-96.

Yadav, R., \& Pathak, G. S. (2016). Young consumers' intention towards buying green products in a developing nation: Extending the theory of planned behavior. Journal of Cleaner Production, 135, 732-739.

Yang, H. C., Liu, H., \& Zhou, L. (2012). Predicting young Chinese consumers' mobile viral attitudes, intents and behavior. Asia Pacific Journal of Marketing and Logistics, 24(1), 59-77.

Zeithaml, V. A., Berry, L. L., \& Parasuraman, A. (1996). The behavioral consequences of service quality. Journal of Marketing, 60(2), 31-46. 